高齢者施設における AMR 対策に関する研究

一有料老人ホームと介護保険施設における「拡げない対策」の実態調查—

吳 禮媛 ${ }^{1,2} \cdot$ ・ 網中眞由美 ${ }^{1)}$ ・森 $\quad$ 那美子 $^{1)}$ ・西岡みどり ${ }^{1)}$

\title{
Antimicrobial Resistance Measures at Facilities for the Elderly: A Fact-finding Survey on Infection Control Measures at Private Nursing Homes and Long-term Care Insurance Facilities
}

\author{
Yeiwon $\mathrm{OH}^{1,2)}$, Mayumi AmINAKA ${ }^{1)}$, Namiko MORI ${ }^{1)}$ and Midori NishiOKA ${ }^{1)}$ \\ ${ }^{1)}$ National College of Nursing, ${ }^{2)}$ Akiru Municipal Medical Center
}

(2019 年 7 月 25 日受付 $\cdot 2020$ 年 9 月 25 日受理)

\begin{abstract}
要旨
本研究では，有料老人ホームと介護保険施設における薬剂耐性 Antimicrobial resistance (AMR) 対策の実態を明らかにし，AMR 対策のあり方を検討することを目的とした．無作為抽出した高齢 者施設 (有料老人ホーム, 介護老人福祉施設, 介護老人保健施設, 介護療養型医療施設), 計 2,800 施設の感染管理担当者を対象に自記式質問紙調査を行った.

254 施設 (9.1\%) の回答を集計した. 有料老人ホームは薬剤耐性菌が拡がりにくい条件が揃って いたが, 他の施設類型と同様に MRSA, ESBL 産生菌, CRE, MDRP, MDRA, VREによる集団 感染が発生していた。高齢者施設の AMR 対策は, マニュアル配備, 研修, 入所時対策などが不十 分であった，入所時スクリーニングの実施率は 22 - 33\%であり，対象菌はほぼMRSAに限定され ており, 薬剤耐性菌を拡げやすいケア（尿道留置カテーテル管理, おむつケアなど）における対策 にも課題があった。したがって, 見落とされた保菌者の薬剤耐性菌を拡げやすいケアを介した拡大 リスクが示された。

高齢者施設の AMR 対策は，入所時スクリーニングを行わず，すべての入所者の薬剤耐性菌を拡 げやすいケアの際に, 標準予防策に加えて接触予防策を強化することが有効と考える. また, 保健 所や地域中核病院からの支援を推進するために診療・介護報酬によるインセンティブも必要と考え る.
\end{abstract}

Key words : 有料老人ホーム, 介護保険施設, 薬剤耐性, 医療関連感染, 感染管理

序文

薬剂耐性菌による医療関連感染は, 入院期間延長, 死 亡率上昇, 医療費増加などの重大な問題を引き起こす1,22. 病院と高齢者施設を行き来する患者の薬剤耐性菌集団感 染が指摘されている ${ }^{3.4)}$. 高齢者施設に打ける薬剤耐性菌 のリスクには, 尿道留置カテーテル年), 裖瘡処置 6.7$)$, 気 管カニューレ8.99, 経管栄養 10.11 , 抢むつケアが報告され ている ${ }^{12.13)}$. 高齢者施設は, 地域包括ケアシステムの強 化により年々施設数が増えている ${ }^{14,15)}$. 高齢者施設には, 介護保険法による介護保険施設（介護老人福祉施設, 介

1)国立看護大学校, 2) 公立阿伎留医療センター
護老人保健施設, 介護療養型医療施設 [平成 30 年より 「介護医療院」一転換］）と，老人福祉法に上る高齢者向 け住まい（有料老人ホーム, 養護老人ホーム, 軽費老人 ホーム, サービス付き高齢者向け住宅, 認知症高齢者グ ループホーム)などがある ${ }^{16)}$.急増している有料老人ホー ムは約 13,000 施設あり, 高齢者施設の中で最も多い ${ }^{14.15)}$. 高齢者施設に扔ける「AMR 対策」の実態についての調 查は有料老人ホームを対象としたものはなく，3 種の介 護保険施設を対象に行われている ${ }^{17 \sim 19)}$. しかし, 先述し たような, 薬剤耐性菌のリスクとなる尿道留置カテーテ ルや裖瘡などに関するケアの実態は不明である.

そこで本研究では, 有料老人ホームと介護保険施設に 
おける AMR 対策の実態を明らかにし，高齢者施設の施 設類型に適したあり方を検討することを目的とした。

\section{用語の定義}

\section{1. 高齢者施設}

高齢者施設を, 有料老人ホームおよび 3 種の介護保険 施設 (介護老人福祉施設 [以下, 特養], 介護老人保健 施設 [以下, 老健 $]$, 介護療養型医療施設 [以下, 療養 型]）とした。

\section{2. 有料老人ホーム}

有料老人ホームには, 介護保険制度における介護を施 設職員により受けられる「介護付」, 訪問介護・訪問看 護・通所介護などの外部サービスを受けられる「住宅型」, 介護が必要となった場合に入所契約が解除される「健康 型」がある。

本研究では, 有料老人ホームを介護付有料老人ホーム に限定した.

\section{AMR 対策}

AMR 対策には, 抗菌薬の適正使用により薬剤耐性菌 を“作らない対策”と, 保菌・感染したヒトから保菌し ていないヒトへ“拡げない対策”がある20).

本研究では，AMR 対策を“拡げない対策”に限定し， $\lceil\mathrm{AMR}$ 対策マニュアル」「職員教育」「施設外相談」「手 指衛生」「個人防護具」「薬剤耐性菌を拡げやすいケア」 「入所時対策 (入所予定者の薬剂耐性菌に関する情報収 集, 入所時スクリーニング, 薬剤耐性菌保菌者の受け入 れ)」とした，なお，薬剤耐性菌を拡げやすいケアは，薬 剂耐性菌のリスクとなるケアのうち ${ }^{4 \sim 13,21)}$, 高齢者施設 での実施頻度が高いものを選定し「口腔ケア」「経管栄 養」「喀痰吸引」「尿道留置カテーテル管理」「おむつケ ア」「裖瘡処置」の 6 つとした ${ }^{22,23)}$.

\section{材料と方法}

無作為抽出した高齢者施設 2,800 施設（有料老人ホー 么 1,400 施設, 特養 400 施設, 老健 400 施設, 療養型 600 施設）の感染管理を主担当する職員を対象に郵送法によ る質問紙調査を行った．有料老人ホームは全国の地方自 治体ホームページに掲載されている 3,758 施設より乱数 を発生させて無作為抽出した. 介護保険施設は厚生労働 省「介護サービス情報公表システム」で検索された特養 7,724 施設, 老健 4,242 施設, 療養型 1,158 施設より同様 に抽出した. 回収率を, 有料老人ホームは初めての調査 対象であるため $10 \%$, 特養と老健は先行調査を参考に $30 \%{ }^{18,24)}$, 療養型は介護医療院への転換直前であるため $20 \%$ と見込み, 各 100 施設以上の回答が得られる配布 数を算出した. 調査項目は網羅的な文献レビューをして 抽出し, 高齢者施設の感染管理担当者 3 名と病院の感染 管理専門家 3 名が内容妥当性を検討した。調査票の表面
妥当性は, 高齢者施設の感染管理担当者 5 名によるプレ テストを行い確認した。

調査項目は, 回答者属性, 施設属性, AMR 対策の実 施状況に関する 145 項目とした。 正確な「AMR 対策の 実施状況」を質問紙調査で明らかにすることは困難であ るため, 本研究では「AMR 対策の実施状況」の代りに 「感染管理担当者が職員の AMR 対策の実施状況を心配 する程度」を 5 段階（とても心配している・やや心配し ている・どちらとも言えない・あまり心配していない・ 全く心配していない) で問うた５段階回答のうち，“あ まり心配していない”または“全く心配していない”と 回答した割合を実施率とした。

調査票は，2018 年 3 月 1 日に郵送し 3 月 20 日を返送 期限とした。変数の種類と分布に応じて, Fisherの正 確確率検定，Wilcoxonの順位和検定，Kruskal-Wallis 検定を行った。多重比較には, Steel-Dwass 検定を用い た。有意水準は $\alpha=0.05$ とした。解析には, $\mathrm{SAS}^{\circledR} 9.4$ ソ フトウェア (SAS institute Inc.) を用いた。本研究は, 国立国際医療研究センター倫理審査委員会の承認を得た (NCGM-G-002436-00).

\section{結果}

257 施設から回答があった。そのうち, 有料老人ホー 厶 3 施設は無回答が $30 \%$ 以上あったため除外した。集 計対象は，有料老人ホーム 137 施設（回収率 $9.8 \%$ ), 特 養 37 施設 $(9.3 \%)$, 老健 46 施設 $(11.5 \%)$, 療養型 34 施 設 $(5.7 \%)$ ，計 254 施設 $(9.1 \%)$ であった.

\section{1. 回答者属性}

回答者は，いずれの施設類型でも看護職が多かったが, 施設類型別により差があり $(p=.044)$, 有料老人ホーム が $61.8 \%$ ，特養が $78.4 \%$ ，老健が $90.9 \%$ ，療養型が $81.8 \%$ であった. 回答者のうち, 「正式に感染管理担当者とし て任命」されていたのは施設類型により差があり（ $p$ $<.001)$, 有料老人ホームが $39.7 \%$, 特養が $62.2 \%$, 老健 が $68.2 \%$, 療養型 $48.5 \%$ であった。

\section{2. 施設属性}

施設属性を表 1-1〜3 に示す.

\section{1）施設属性概要}

入所定員の中央值は, 有料老人ホームが 48.0 人であ り，特養の 80.0 人，老健の 100.0 人より少なかった（そ れぞれ $p<.001, p<.001)$. 療養型の 37.5 人は特養と老 健より少なかった（それぞれ $p=.019, p=.002)$. 在所日 数の中央值は, 有料老人ホームが 1040.0 日, 特養が 1015.5 日であり，老健の 397.7 日（それぞれ $p<.001, p$ <.001), 療養型の 389.5 日より長かった（それぞれ $p$ $<.001, p=.001)$. 個室数の中央值は, 有料老人ホーム が 42 室, 特養が 40 室であり，老健の 9.5 室（それぞれ $p<.001, p=.040)$, 療養型の 2.5 室より多かった（それ 


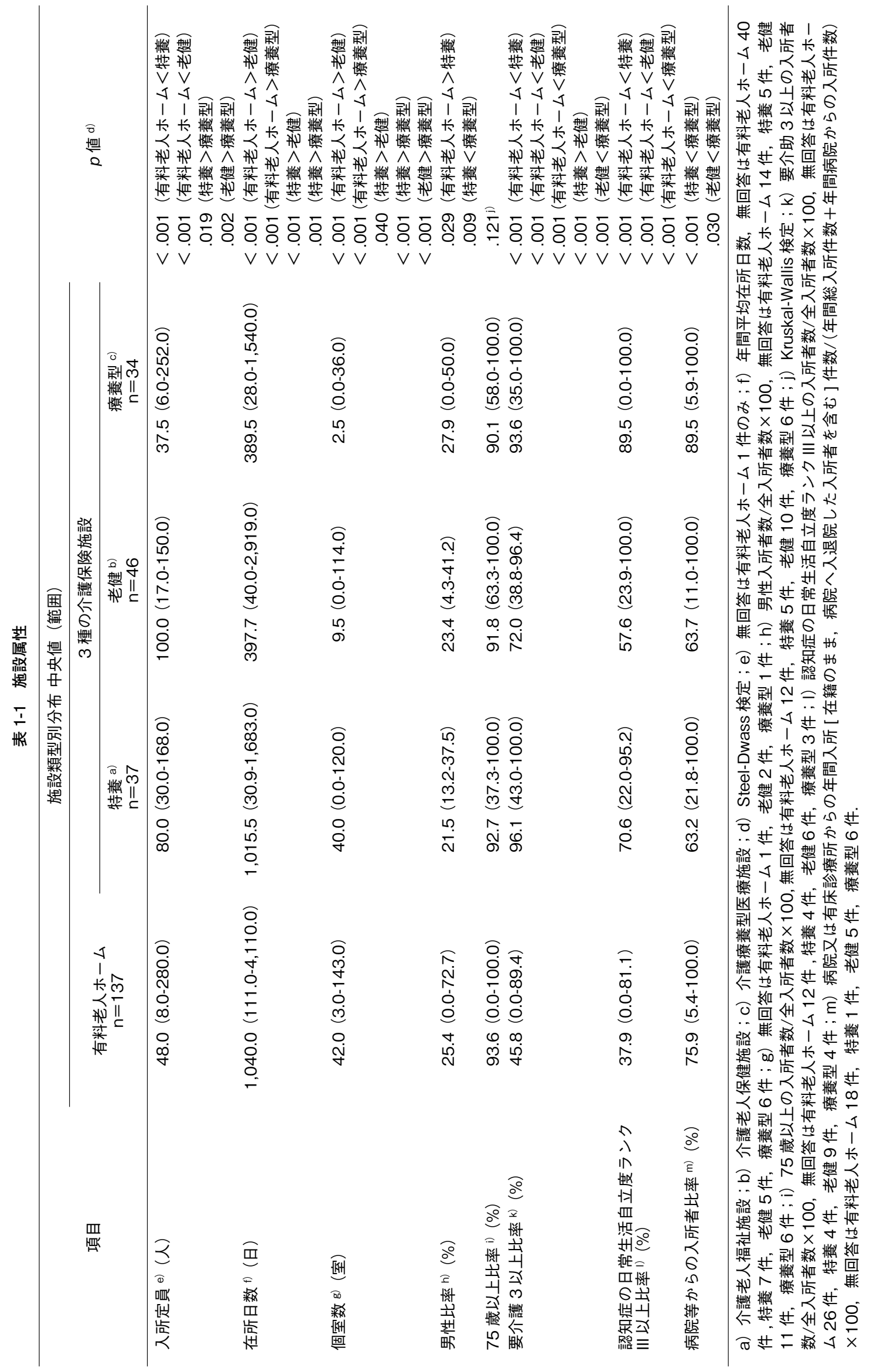




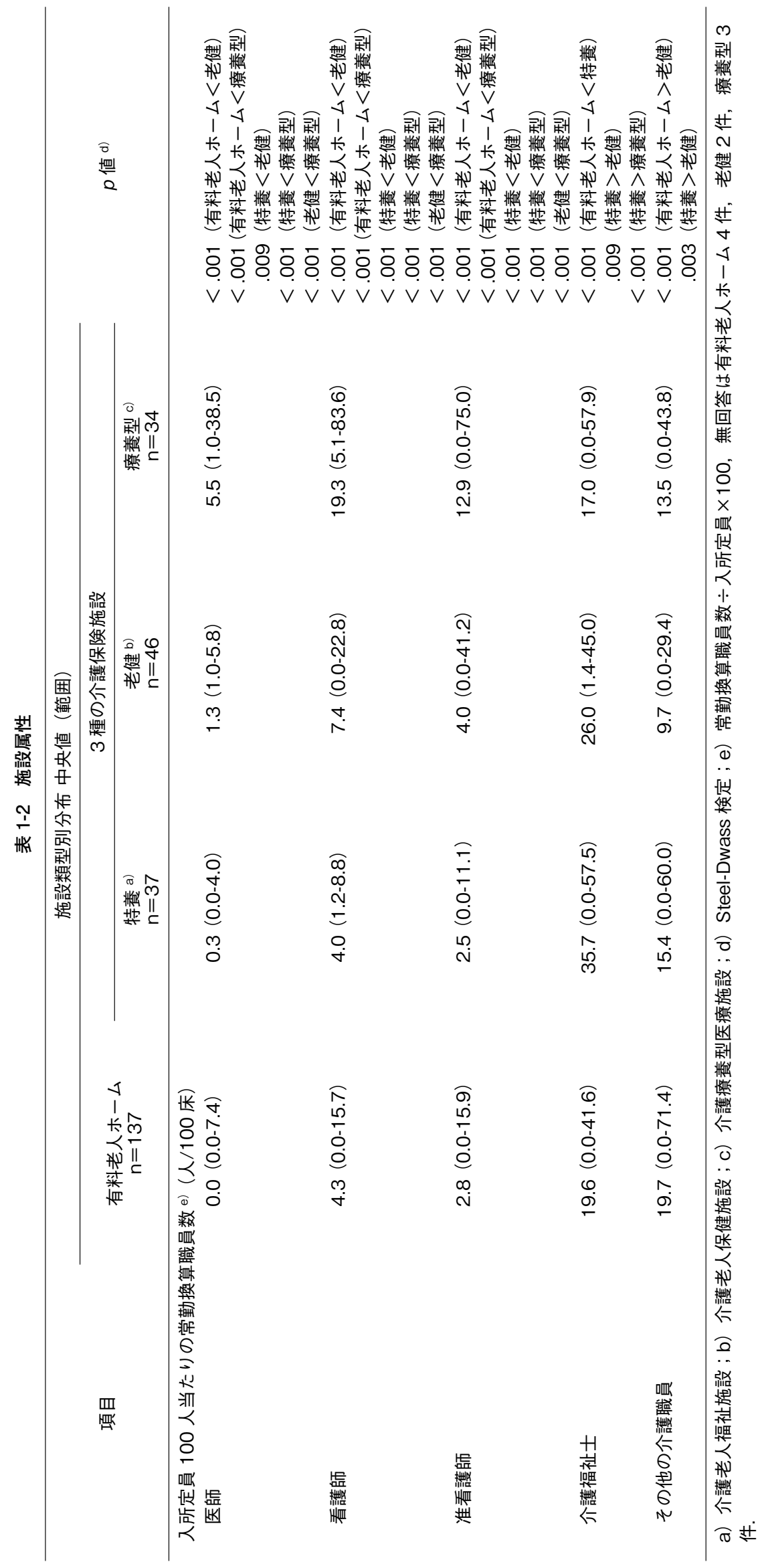




\begin{tabular}{|c|c|c|c|c|c|}
\hline & \multicolumn{4}{|c|}{ 施設類型別分布 \% } & \multirow{3}{*}{$p$ 値 d) } \\
\hline & \multirow{2}{*}{$\begin{array}{c}\text { 有料老人ホーム } \\
\mathrm{n}=137\end{array}$} & \multicolumn{3}{|c|}{3 種の介護保険施設 } & \\
\hline & & $\begin{array}{l}\text { 特養 a) } \\
\mathrm{n}=37\end{array}$ & $\begin{array}{l}\text { 老健 }^{b)} \\
\mathrm{n}=46\end{array}$ & $\begin{array}{l}\text { 療養型 c) } \\
\mathrm{n}=34\end{array}$ & \\
\hline $\begin{array}{l}\text { 日常的に細菌検査を実施（外注を含む）e） } \\
\text { 検査内容（※複数回答） }\end{array}$ & 22.7 & 24.3 & 71.8 & 94.1 & $<.001$ \\
\hline 一般細菌塗抹検査 & 12.9 & 18.9 & 60.9 & 88.2 & $<.001$ \\
\hline 一般細菌培養検査（同定, 定量, 感受性） & 14.4 & 18.9 & 63.0 & 82.4 & $<.001$ \\
\hline 抗酸菌培養検査（PCR を含む） & 7.6 & 5.4 & 41.3 & 70.6 & $<.001$ \\
\hline 嫌気培養検査 & 6.1 & 5.4 & 39.1 & 67.7 & $<.001$ \\
\hline MRSA 検査 & 18.2 & 21.6 & 58.7 & 79.4 & $<.001$ \\
\hline ESBL 産生菌検査 & 6.1 & 8.1 & 32.6 & 61.8 & $<.001$ \\
\hline CRE 検査 & 4.5 & 2.7 & 23.9 & 47.1 & $<.001$ \\
\hline MDRP 検査 & 8.3 & 13.5 & 28.3 & 58.8 & $<.001$ \\
\hline MDRA 検査 & 4.5 & 5.4 & 23.9 & 58.8 & $<.001$ \\
\hline VRE 検査 & 7.6 & 5.4 & 26.1 & 55.9 & $<.001$ \\
\hline \multicolumn{6}{|l|}{ 過去の薬剂耐性菌集団感染 f) の経験（※複数回答） } \\
\hline ESBL 産生菌 & 5.1 & 2.7 & 8.9 & 14.7 & .027 \\
\hline MRSA & 4.4 & 5.4 & 6.7 & 6.3 & .733 \\
\hline CRE & 2.2 & 0.0 & 6.7 & 6.3 & .116 \\
\hline MDRP & 2.2 & 0.0 & 4.4 & 6.3 & .201 \\
\hline MDRA & 2.2 & 0.0 & 2.2 & 3.1 & .736 \\
\hline VRE & 2.9 & 0.0 & 2.2 & 6.3 & .342 \\
\hline \multicolumn{6}{|c|}{ 直近 1 年間 g) の薬剂而性菌集団感染の経験（※複数回答） } \\
\hline ESBL 産生菌 & 2.9 & 2.7 & 6.7 & 12.5 & .030 \\
\hline MRSA & 1.5 & 5.4 & 4.4 & 6.3 & .011 \\
\hline CRE & 0.0 & 0.0 & 2.2 & 0.0 & .290 \\
\hline
\end{tabular}

PCR : Polymerase Chain Reaction, ポリメラーゼ連鎖反応; MRSA：Methicillin resistant Staphylococcus aureus, メチシリ ン耐性ブドウ球菌；ESBL：Extended spectrum $\beta$-lactamases, 基質特異性拡張型 $\beta$ ラクタマーゼ；CRE：Carbapenem resistant enterobacteriaceae, カルバペネム耐性腸内細菌科細菌；MDRP：Multidrug resistant Pseudomonas aeruginosa, 多剂耐 性緑膿菌；MDRA：Multidrug resistant Acinetobacter spp, 多剂而性アシネトバクター属菌；VRE：Vancomycin resistant Enterococcus, バンコマイシン耐性腸球菌.

a）介護老人福祉施設；b）介護老人保健施設；c）介護療養型医療施設；d）Fisher の正確確率検定；e）無回答は有料老人ホー ム 5 件のみ； f) 集団感染は感染症（保菌を除く）が同時に 2 例以上発生した事象，無回答は有料老人ホーム 2 件，老健 1 件， 療養型 2 件；g）直近 1 年間は調査日までの直近 1 年または前年度（平成 28 年度）, 無回答は有料老人ホーム 2 件, 老健 1 件, 療養型 2 件.

ぞれ $p<.001, p<.001)$. 老健の個室数も，療養型より 多かった $(p<.001)$. いずれの施設類型でも女性が男性 より多く，男性比率は有料老人ホームが $25.4 \%$, 療養型 が $27.9 \%$ であり, 特養の $21.5 \%$ より高かった（それぞれ $p=.029, p=.009)$. 高齢者施設では, いずれの施設類型 でも 75 歳以上の入所者が 9 割以上であった. 要介護度 3 以上の入所者比率は, 有料老人ホームが $45.8 \%$ であり, 特養の $96.1 \%$, 老健の $72.0 \%$, 療養型の $93.6 \%$ より低かっ た（それぞれ $p<.001, p<.001, p<.001)$. 老健の要 介護度 3 以上の入所者比率は, 特養と療養型より低かっ た（それぞれ $p<.001, p<.001)$. 認知症の日常生活自 立度ランク III 以上の入所者比率は, 有料老人ホームが $37.9 \%$ であり, 特養の $70.6 \%$, 老健の $57.6 \%$, 療養型の $89.5 \%$ より低かった（それぞれ $p<.001, p<.001, p$ $<.001)$.
年間総入所者に占める病院（または有床診療所）から の入所者比率の中央值は, 療養型が $89.5 \%$ であり, 特養 の $63.2 \%$ ，老健の $63.7 \%$ より高かった（それぞれ $p<.001$, $p=.030$ ). なお, 有料老人ホームは $75.9 \%$ であった.

入所定員 100 人当たりの常勤換算医師数の中央值は, 有料老人ホームが 0.0 人, 特養の 0.3 人であり, 老健の 1.3 人 (それぞれ $p<.001, p=.009)$, 療養型の 5.5 人よ り少なかった (それぞれ $p<.001, p<.001)$. 老健の医 師数は, 療養型より少なかった $(p<.001)$. 看護師数は, 有料老人ホームが 4.3 人, 特養が 4.0 人であり, 老健の 7.4 人 (それぞれ $p<.001, p<.001)$, 療養型の 19.3 人 より少なかった（それぞれ $p<.001, p<.001)$. 老健の 看護師数は, 療養型より少なかった $(p<.001)$. 准看護 師数も, 有料老人ホームが 2.8 人, 特養が 2.5 人であり, 老健の 4.0 人（それぞれ $p<.001, p<.001$ ), 療養型の 
12.9 人より少なかった（それぞれ $p<.001, p<.001)$. 老健の准看護師数も, 療養型より少なかった $(p<.001)$. 介護福祉士数は特養が 35.7 人であり, 有料老人ホーム の 19.6 人, 老健の 26.0 人, 療養型の 17.0 人より多かっ た（それぞれ $p<.001, p=.009, p<.001)$. その他の介 護職員は, 有料老人ホームが 19.7 人, 特養が 15.4 人で あり，老健より多かった（それぞれ $p<.001, p=.003)$.

\section{2）細菌検査の実施}

日常的に細菌検査を実施している施設は施設類型によ り差があり $(p<.001)$, 有料老人ホームが $22.7 \%$, 特養 が $24.3 \%$ ，老健が $71.8 \%$ ，療養型が $94.1 \%$ であった。一 般細菌培養検査（同定, 定量, 感受性）の実施率は施設 類型により差があり $(p<.001)$, 有料老人ホームが $14.4 \%$, 特養が $18.9 \%$ ，老健が $63.0 \%$ ，療養型が $82.4 \%$ であった。 いずれの施設類型でも MRSA 検査が多く実施されてい たが, 施設類型により差があり $(p<.001)$, 有料老人ホー ムが $18.2 \%$, 特養が $21.6 \%$, 老健が $58.7 \%$, 療養型が $79.4 \%$ であった。

\section{3）集団感染の経験}

集団感染は, 感染症（保菌を除く）が同時に 2 例以上 発生した事象とした。基質特異性拡張型 $\beta$-ラクタマー ゼ Extended-spectrum $\beta$-lactamase (ESBL) 産生菌に よる集団感染経験率は, 施設類型により差があり（ $p$ $=.027$, 有料老人ホームが $5.1 \%$, 特養が $2.7 \%$, 老健が $8.9 \%$, 療養型が $14.7 \%$ であった. メチシリン耐性黄色ブ ドウ球菌 Methicillin resistant Staphylococcus aureus （MRSA）による集団感染の経験は施設類型による差は なく $4.4 \%$ 6.7\% であった. 特養以外の 3 施設類型の集 団感染経験率は, カルバペネム耐性腸内細菌科細菌 Carbapenem-resistant Enterobacteriaceae (CRE) が 2.2 6.7\%, 多剂耐性緑膿菌 Multidrug resistant Pseudomonas aeruginosa (MDRP) が 2.2〜 6.3\%, 多剂耐性ア シネトバクター属菌 Multidrug resistant Acinetobacter spp. (MDRA) が 2.2〜3.1\%，バンコマイシン耐性腸球菌 Vancomycin resistant Enterococcus (VRE) が 2.2〜6.3\% であった。

直近 1 年間（または前年度［平成 28 年度］）の集団感 染経験率は, ESBL 産生菌と MRSA で施設類型による 差があった $(p=.030, p=.011)$. 経験率は ESBL 産生菌 と MRSAの順に有料老人ホームでは $2.9 \%$ と $1.5 \%$, 特 養では $2.7 \%$ と $5.4 \%$, 老健では $6.7 \%$ と $4.4 \%$, 療養型で は $12.5 \%$ と $6.3 \%$ であった. 他方, $\mathrm{CRE}$ の集団感染経験 率に施設類型による差はなく 0.0 ～ $2.2 \%$ であった. 直近 1 年間に VRE, MDRP, MDRAの集団感染を経験して いた施設はなかった。

\section{AMR 対策の実施状況}

AMR 対策の実施状況を表 2 に示す.

\section{1） $\mathrm{AMR}$ 対策マニュアル}

AMR 対策マニュアルの配備率（包括的マニュアルに AMR 対策の内容が含まれる場合，または，AMR 対策 に特化したマニュアルがある場合）は 41.2～61.8\% であ り, マニュアルがある施設の約 9 割で, AMR 対策マニュ アルに「MRSA 対策」が含まれていた。しかし，「ESBL 産生菌対策 $(p=.005) 」 「 \mathrm{CRE}$ 対策 $(p=.005) 」 「 \mathrm{MDRA}$ 対策 $(p<.001) 」 「 \mathrm{VRE}$ 対策 $(p=.035) 」$ がマニュアル に含まれていた施設の割合は施設類型によりばらつきが あった。 入所予定保菌者や感染者の AMR 対策に自施設 マニュアルを活用していた高齢者施設は，施設類型によ り差があり $(p=.032)$, 有料老人ホームの $14.8 \%$, 特養 の $25.0 \%$ ，老健の $4.3 \%$, 療養型の $14.3 \%$ であった.

\section{2）職員教育}

直近 1 年間（または前年度 [平成 28 年度]）の AMR 対策研修会開催率は，施設類型により差があり $(p=.013)$, 有料老人ホームが $18.7 \%$, 特養が $8.1 \%$, 老健が $26.1 \%$, 療養型が $38.2 \%$ であった。研修会を開催している施設の 61.5〜84.0\% では，研修内容に MRSA 対策が取り上げら れていた。

\section{3）施設外相談}

感染対策について施設外に相談している施設は 60.0 $73.9 \%$ であった，施設外相談をしている施設のうち，療 養型以外では, 8 割以上の相談先が関連施設（併設・隣 接・提携の病院または診療所, 訪問看護ステーション) であった. 保健所に相談していた施設は 39.5 63.0\% で あった. 感染管理専門家や感染対策地域ネットワーク (以 下，ネットワーク）に相談している施設は，施設類型に より差があり $(p<.001)$, 有料老人ホームが $11.1 \%$, 特 養が $25.9 \%$ ，老健が $29.4 \%$ ，療養型が $63.6 \%$ であった。

\section{4）手指衛生}

いずれの施設類型でも 85.3 91.2\% の施設で手指衛生 の徹底を AMR 対策として重視していた. しかし，すべ ての医療介護職員に携帯用手指消毒剤を配布していたの は，有料老人ホームでは $13.2 \%$, 特養では $5.4 \%$, 老健で は $17.4 \%$, 療養型では $14.7 \%$ であった。

手指衛生タイミングのマニュアル記載率および実施率 (感染管理担当者が職員の実施状況を心配しない割合)を 図 1 に示す。手指衛生タイミングのマニュアルの記載 率は「喀痰吸引前 $(p=.014) 」 「$ 喀痰吸引後 $(p=.004) 」$

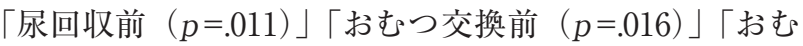
つ交換後 $(p=.025) 」 て ゙$ 施設類型により差があった．実 施率は「口腔ヶア後 $(p=.001) 」 「$ 裖瘡処置後 $(p=.033) 」$ 「使い捨て手袋を外した後 $(p=.007) 」 て ゙$ 施設類型によ り差があった。

5）個人防護具

使い捨て手袋や使い捨てエプロン（またはガウン）使 用のマニュアル記載率と実施率を図 2 に示す。使い捨 


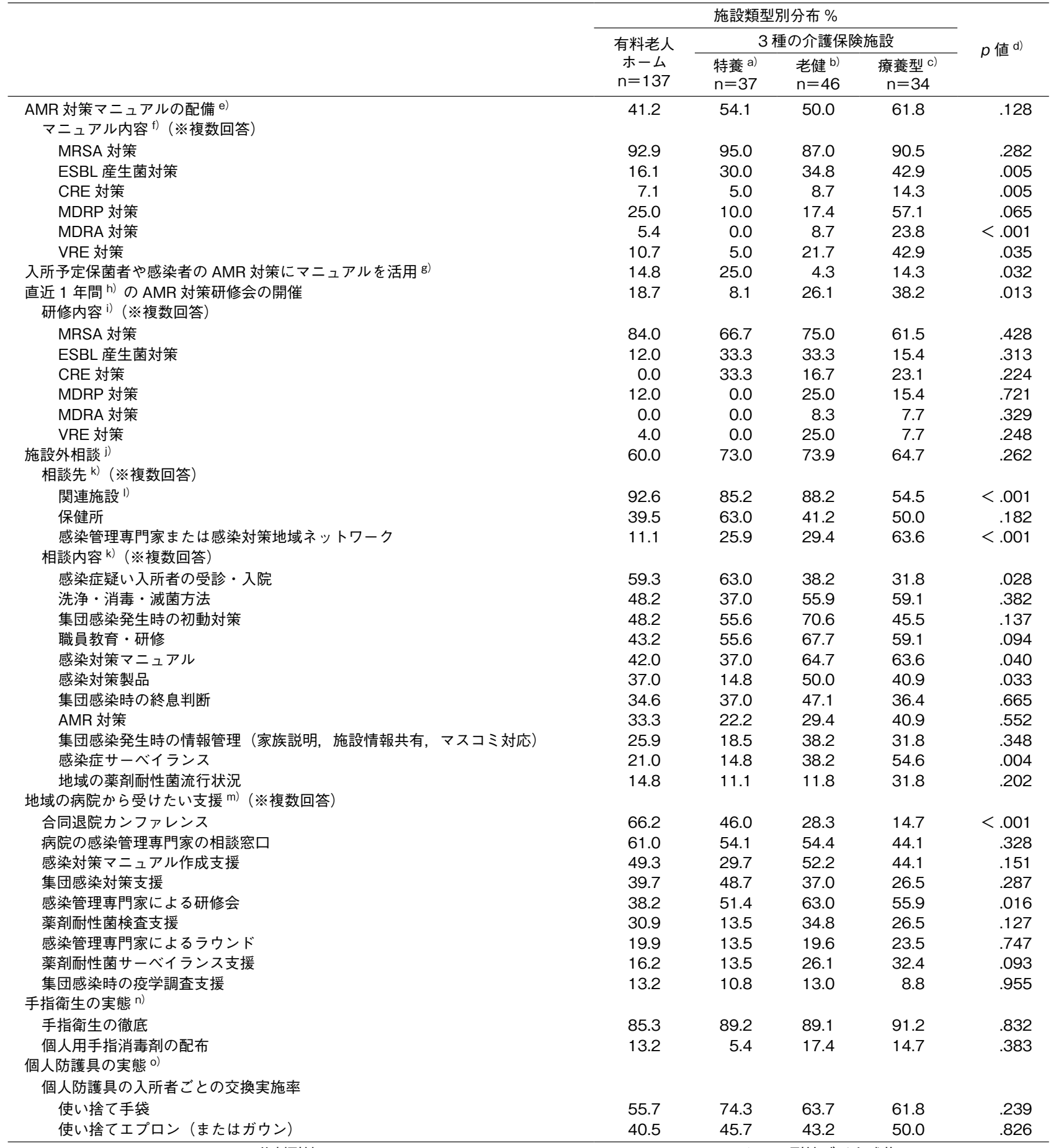

AMR : Antimicrobial resistance, 薬剂耐性；MRSA：Methicillin resistant Staphylococcus aureus, メチシリン耐性ブドウ球菌；ESBL：Extended spectrum $\beta$-lactamases, 基質特異性拡張型 $\beta$ ラクタマーゼ；CRE : Carbapenem resistant enterobacteriaceae, カルバペネム耐性腸内細菌科細菌； MDRP : Multidrug resistant Pseudomonas aeruginosa, 多剂而性緑膿菌; MDRA : Multidrug resistant Acinetobacter spp, 多刘而性アシネトバク ター属菌；VRE：Vancomycin resistant Enterococcus, バンコマイシン耐性腸球菌.

a) 介護老人福祉施設；b）介護老人保健施設；c）介護療養型医療施設；d）Fisher の正確確率検定；e）無回答は有料老人ホーム 1 件のみ；f）nは AMR 対策マニュアルがある施設のみ（有料老人ホーム 56 件, 特養 20 件, 老健 23 件, 療養型 21 件）；g）無回答は有料老人ホーム 7 件，療養型 1 件；h）直近 1 年間は調査日までの直近 1 年または前年度（平成 28 年度），無回答は有料老人ホーム 3 件のみ；i） $\mathrm{n}$ は直近 1 年間に薬剤耐性菌研 修会を開催した施設のみ（有料老人ホーム 25 件, 特養 3 件, 老健 12 件, 療養型 13 件）；j）無回答は有料老人ホーム 2 件のみ； $\mathrm{k} ） \mathrm{n}$ は施設外に 相談している施設のみ（有料老人ホーム 81 件，特養 27 件，老健 34 件，療養型 22 件）；）関連施設は併設・隣接・提携の病院または診療所, 訪 問看護ステーション；m）無回答は有料老人ホーム 1 件のみ；n）無回答は有料老人ホーム 1 件のみ；o）無回答は有料老人ホーム 6 件, 特養 2 件, 老健 2 件. 


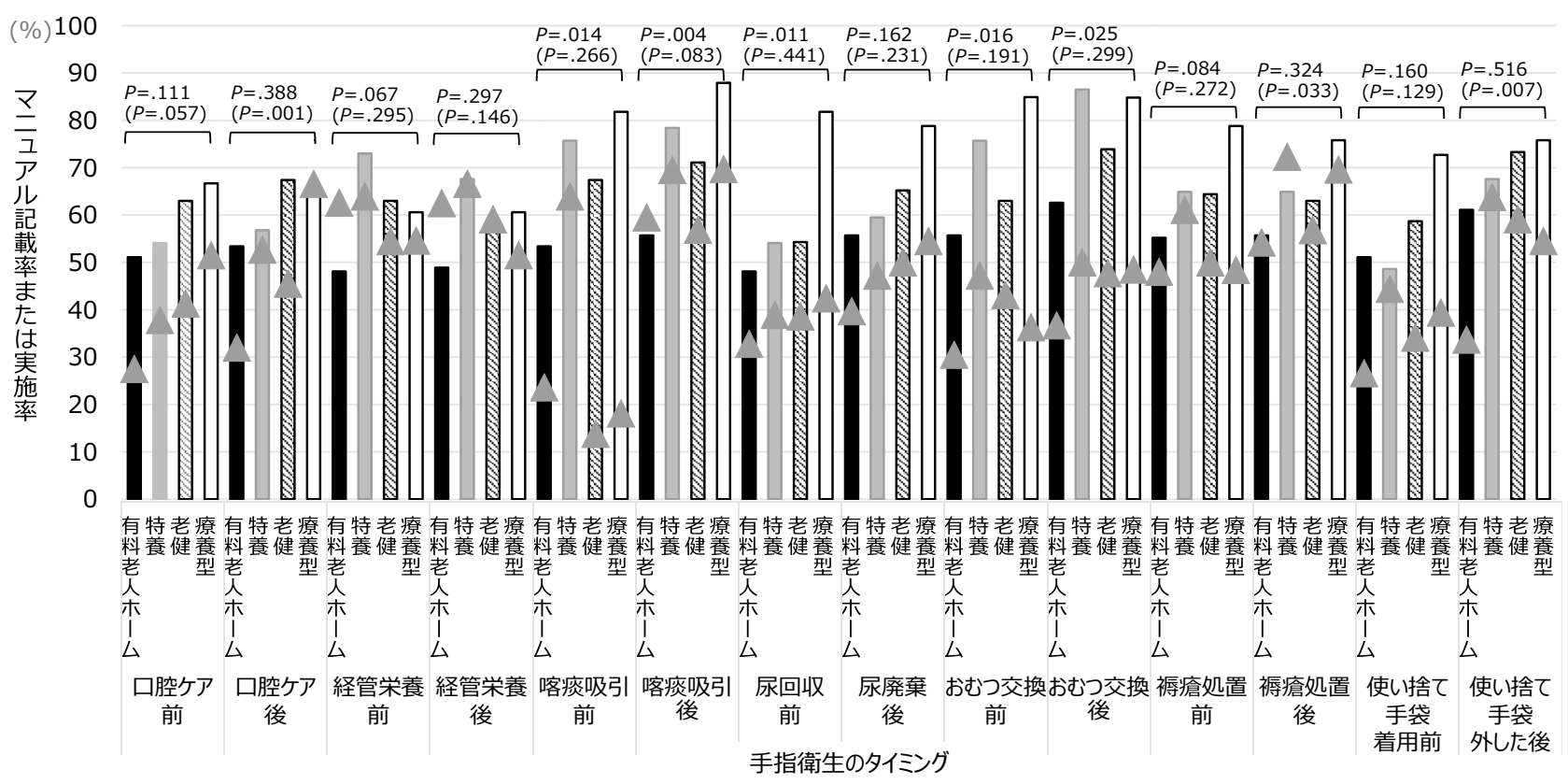

図 1 手指衛生タイミングのマニュアル記載率及び実施率

$\mathrm{n}$ は, 有料老人ホーム 137 件 (無回答 6 件), 特養 37 件, 老健 46 件, 療養型 34 件 (無回答 1 件)。

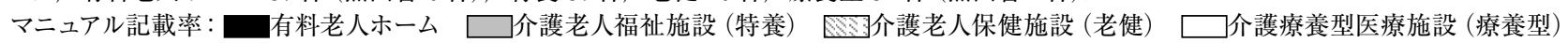
実施率; $\boldsymbol{\Delta}$, 感染管理担当者が職員の実施を「とても心配」「やや心配」「どちらとも言えない」「あまり心配していない」「全く心配してい ない」の 5 段階で回答, 実施率は「あまり心配していない」「全く心配していない」と回答した割合.

（）がない $p$ 值は，マニュアル記載率の施設間差の検定結果.

（ ）の中の $p$ 值は，実施率の施設間差の検定結果.

て手袋は使い捨てエプロン(またはガウン)よりもマニュ アルに記載され, 使用される傾向にあった. 使い捨てエ プロン（またはガウン）は，有料老人ホームと特養のマ ニュアルの記載率が低く，使用されない傾向にあった。

また, 個人防護具の入所者ごとの交換実施率は, 使い 捨て手袋が55.7〜 74.3\% が，使い捨てエプロン（または ガウン）が 40.5〜 50.0\% であった（表 2).

6）薬剂耐性菌を拡げやすいケアの実態

薬剤耐性菌を拡げやすいケアの実態を表 3 に示す.

尿道留置カテーテル管理を実施していた施設のうち, 87.4 100.0\% がカテーテルやチューブが折れ曲がらない ように注意し，87.4〜97.0\% がバッグを膀胱より低い位 置に維持し，77.3〜 91.4\%がカテーテル入れ替え時には バックも交換していた。一方, 尿回収後にバックの排液 口をアルコール綿で消毒したり, 毎日陰部清拭をしたり, 携帯式膀胱エコーにより残尿量計測を行って適応を検討 したりする施設はいずれの施設類型でも半数以下であっ た.

おむつカートを使用していた施設のうち，60.0〜 81.8\% がおむつ, リネン類, 個人防護具, 䙏瘡 ·創傷物品, 陰 部洗浄ボトルなどの使用前物品と使用後物品を混載して いたおおむカートの廃止を検討していた施設はほとん どなかった。
喀痰吸引を実施していた施設のうち，61.8～75.0\%が 喀痰吸引カテーテルを再利用し， 25.0 47.6\% が再利用 のために浸漬消毒を行っていた.

経管栄養を実施していた施設のうち，57.8～75.0\%が 投与容器を，78.1〜97.6\% が経管栄養ラインを，61.3〜 81.8\% が経鼻栄養チューブを, すべてが胃瘻・腸瘦 チューブを，88.9〜100.0\% がカテーテルチップを再利用 していた．経管栄養物品を再利用していた施設のうち, 65.3〜 84.6\% が投与容器を, 60.0 ～82.9\% が経管栄養ライ ンを，57.9〜 75.0\% が経鼻栄養チューブを， 60.0〜80.5\% が胃瘻・腸瘻チューブを, 37.0〜 65.9\% がカテーテルチッ プを浸漬消毒していた，経管栄養物品を乾燥せずに使用 直前まで浸漬消毒していた施設は，5.7〜 8.9\% であった.

7) 入所時対策

入所時対策を表 4 に示す.

（1）入所予定者の薬剂耐性菌に関する情報収集

入所予定者の薬剂耐性菌に関する情報（薬剤耐性菌種 類, 薬剤耐性菌の抗菌薬感受性, 入院中の抗菌薬治療, 退院時の処方抗菌薬, 必要な感染対策, 本人 · 家族へ説 明）を入院先の病院等から「必ず入手している」施設は 18.9 24.1\%であった. 他方, 保菌者や感染者に限ると 97.0 100.0\%の施設が感染対策の情報を入手していた. 感染対策の情報源は, 主に「看護サマリー（63.6〜 

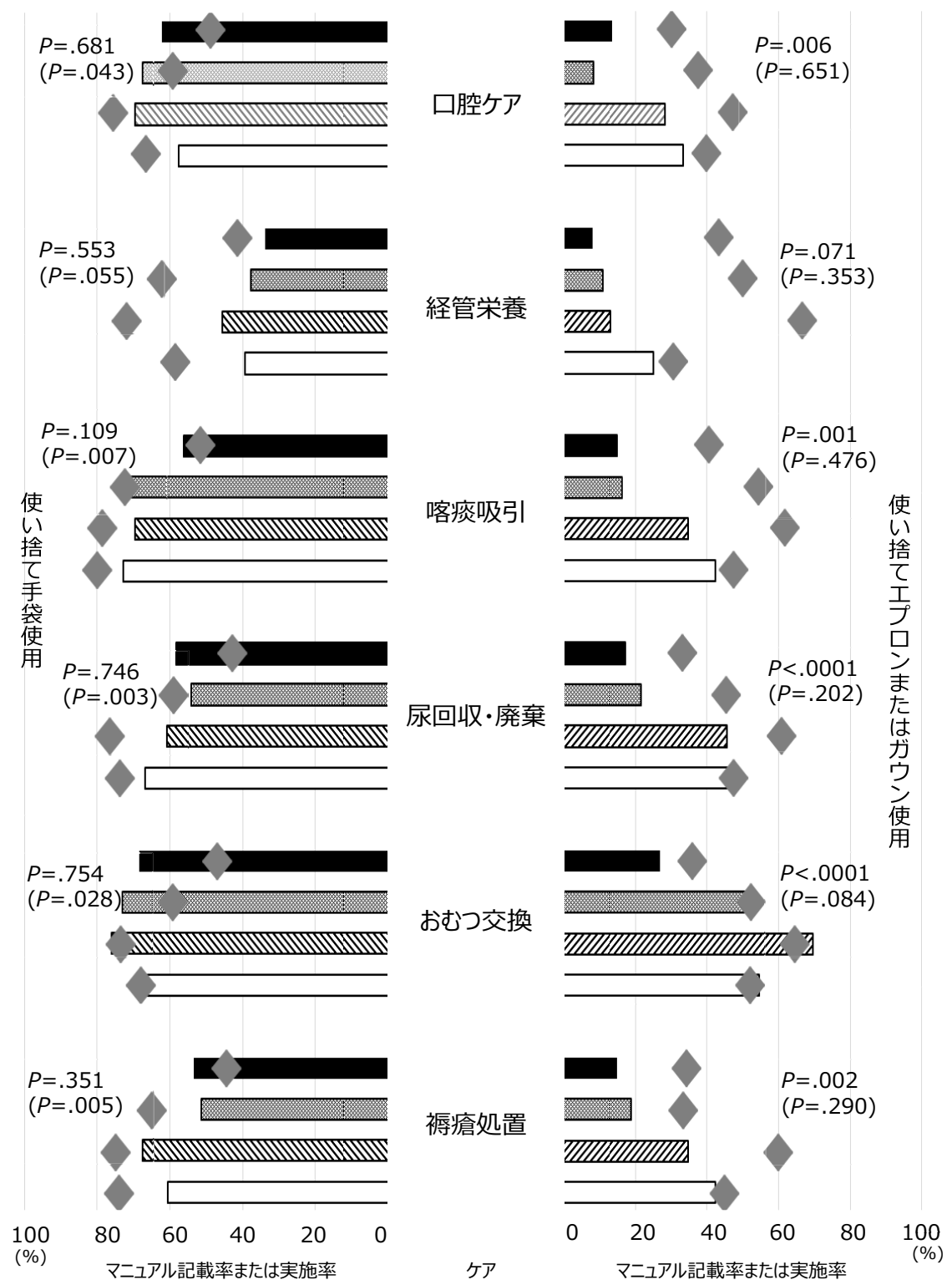

図 2 使い捨て手袋・エプロン（またはガウン）使用のマニュアル記載率及び実施率 $\mathrm{n}$ は, 有料老人ホーム 137 件（無回答 4 件），特養 37 件，老健 46 件，療養型 34 件（無回答 1 件).

マニュアル記載率：口有料老人ホーム $\square$ 介護老人福祉施設（特養） 施設（老健） $\square$ 介護療養型医療施設（療養型）

実施率 ; 「あまり心配していない」「全く心配していない」の5段階で回答, 実施率は「あまり心配して いない」「全く心配していない」と回答した割合。

（）がない $p$ 值は, マニュアル記載率の施設間差の検定結果.

（）の中の $p$ 值は, 実施率の施設間差の検定結果.

78.5\%)」「診療情報提供書 $(60.6 \sim 76.9 \%) 」 て ゙ あ り ， そ$ の他には「入所予定者の介護支援専門員 (21.2 59.5\%)」 「自施設の医師 $(29.7 \sim 47.8 \%) 」 「$ 自施設の看護師 $(21.2 \sim$ $32.3 \%) 」 「$ インーネット (33.3〜 51.4\%)」「保健所 (8.7〜 $16.2 \%) 」 「$ 施設外の感染症専門医または感染対策担当医 師（1.5～13.1\%)」「施設外の感染症看護専門看護師また は感染管理認定看護師（3.1～17.4\%)」であった.
（2）入所予定者の薬剂耐性菌スクリーニングと保菌 者や感染者の受け入れ

入所時スクリーニングを, 有料老人ホームの $33.3 \%$, 特養の $21.6 \%$ ，老健の $21.7 \%$ ，療養型の $26.5 \%$ が実施し ていた，薬剤耐性菌スクリーニングを実施している施設 では，ほとんどがMRSA スクリーニングを実施してい た. $15.7 \sim 51.2 \%$ の施設が MRSA 保菌者や感染者の, 


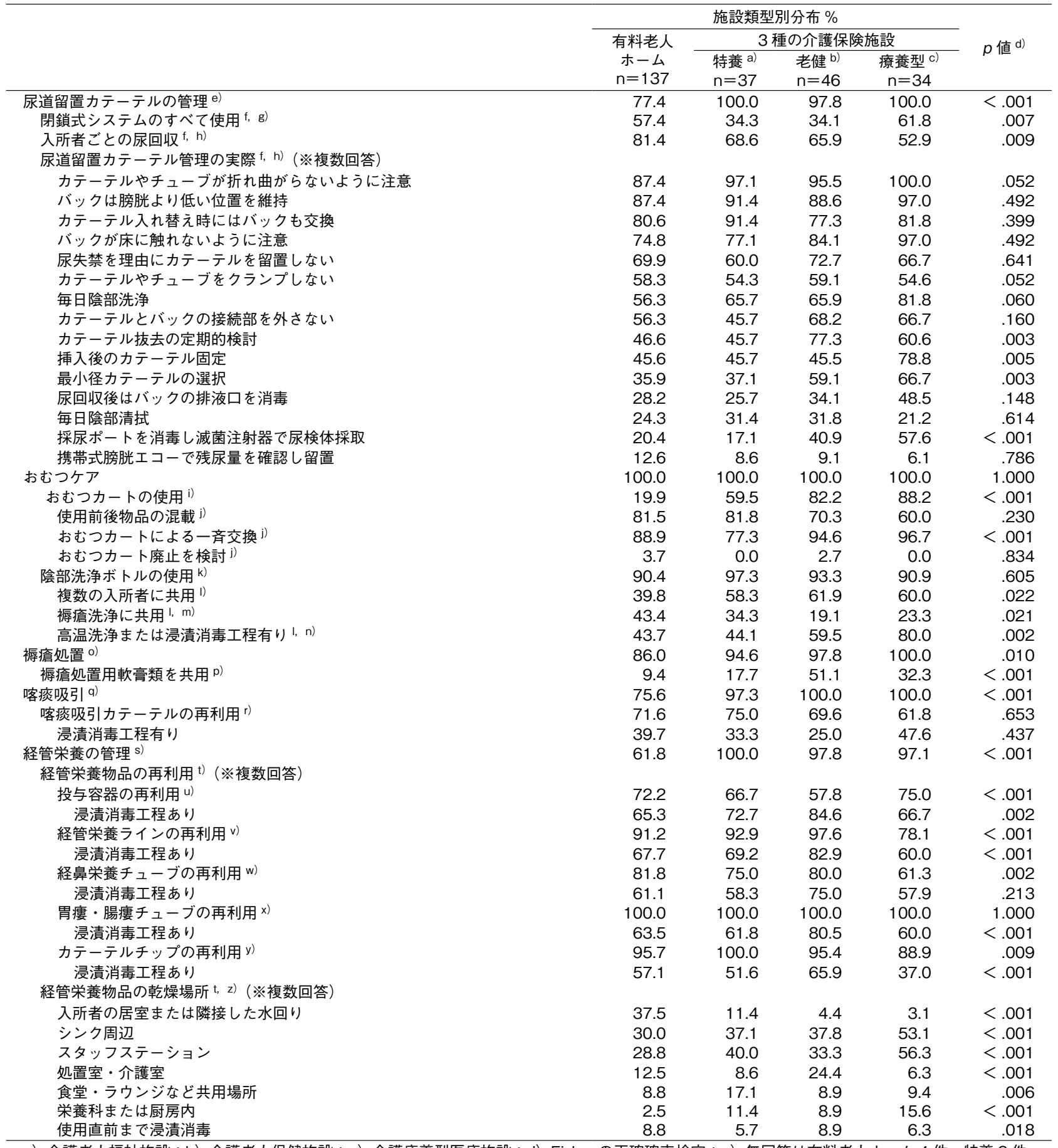

a）介護老人福祉施設；b）介護老人保健施設；c）介護療養型医療施設；d）Fisher の正確確率検定；e）無回答は有料老人ホーム 4 件，特養 2 件， 老健 1 件；f）ｎは尿道留置カテーテル管理を実施している施設のみ（有料老人ホーム 103 件, 特養 35 件, 老健 44 件, 療養型 34 件）；g）無回答 は有料老人ホーム 2 件のみ；h）無回答は有料老人ホーム 1 件のみ；i）無回答は有料老人ホーム 1 件，老健 1 件；j） n はおむつカートを使用して いる施設のみ（有料老人ホーム 27 件, 特養 22 件, 老健 37 件, 療養型 30 件）； k）無回答は有料老人ホーム 1 件, 老健 1 件, 療養型 1 件； I) 陰 部洗浄ボトルを使用している施設のみ（有料老人ホーム 123 件，特養 36 件，老健 42 件，療養型 30 件）；m）無回答は有料老人ホーム 1 件，特養 1 件, 老健 1 件, 療養型 1 件；n）無回答は有料老人ホーム 4 件, 特養 2 件；o）無回答は有料老人ホーム 1 件のみ；p）nは裖痏処置を実施してい る施設のみ（有料老人ホーム 117 件，特養 35 件，老健 45 件，療養型 34 件)，無回答は特養 1 件のみ；q）無回答は，有料老人ホーム 2 件のみ； r） $\mathrm{n}$ は喀痰吸引を実施している施設のみ（有料老人ホーム 102 件, 特養 36 件, 老健 46 件, 療養型 34 件）； s）無回答は有料老人ホーム 1 件の み； t） $\mathrm{n}$ は経管栄養を実施している施設のみ（有料老人ホーム 84 件，特養 37 件，老健 45 件，療養型 33 件)，無回答は有料老人ホーム 10 件， 特養 3 件, 療養型 1 件 ; u ) n は投与容器の再利用施設（有料老人ホーム 52 件, 特養 22 件, 老健 26 件, 療養型 24 件）；v） $\mathrm{n}$ は経管栄養ライン の再利用施設（有料老人ホーム 62 件, 特養 26 件, 老健 41 件, 療養型 25 件）；w）n は経鼻栄養チューブの再利用施設（有料老人ホーム 36 件, 特養 12 件, 老健 24 件, 療養型 19 件）；x） n は胃瘻・腸瘻チューブの再利用施設（有料老人ホーム 74 件, 特養 34 件, 老健 41 件, 療養型 30 件）；y）n はカテーテルチップの再利用施設（有料老人ホーム 67 件，特養 31 件，老健 42 件，療養型 24 件）；z）無回答は有料老人ホーム 4 件， 特養 2 件, 療養型 1 件. 


\begin{tabular}{|c|c|c|c|c|c|}
\hline & \multicolumn{4}{|c|}{ 施設類型別分布 \% } & \multirow{3}{*}{$p$ 值 d) } \\
\hline & \multirow{2}{*}{$\begin{array}{c}\text { 有料老人 } \\
\text { ホーム } \\
n=137\end{array}$} & \multicolumn{3}{|c|}{3 種の介護保険施設 } & \\
\hline & & $\begin{array}{l}\text { 特養 a) } \\
n=37\end{array}$ & $\begin{array}{l}\text { 老健 } \mathrm{b} \text { ) } \\
\mathrm{n}=46\end{array}$ & $\begin{array}{c}\text { 療養型 } \mathrm{c}) \\
\mathrm{n}=34\end{array}$ & \\
\hline \multicolumn{6}{|l|}{ 入所予定者の薬剤而性菌に関する情報 e) 収集 } \\
\hline 必ず入手している & 24.1 & 18.9 & 19.6 & 23.5 & .323 \\
\hline $\begin{array}{l}\text { 入所予定保菌者や感染者の感染対策情報入手 } \\
\text { 情報源 f)（※複数回答） }\end{array}$ & 97.7 & 100.0 & 100.0 & 97.0 & .619 \\
\hline 看護サマリー & 78.5 & 74.7 & 71.7 & 63.6 & .335 \\
\hline 診療情報提供書 & 76.9 & 73.0 & 71.7 & 60.6 & .303 \\
\hline 入所予定者の介護支援専門員 & 47.7 & 59.5 & 26.1 & 21.2 & .065 \\
\hline 自施設の医師 & 33.1 & 29.7 & 47.8 & 30.3 & .243 \\
\hline 自施設の看護師 & 32.3 & 21.6 & 23.9 & 21.2 & .416 \\
\hline インターネット & 40.8 & 51.4 & 45.7 & 33.3 & .446 \\
\hline 保健所 & 11.5 & 16.2 & 8.7 & 12.1 & .758 \\
\hline 施設外の感染症専門医または感染対策担当医師 & 1.5 & 8.1 & 13.1 & 9.1 & .006 \\
\hline 施設外の感染症看護専門看護師または感染管理認定看護師 & 3.1 & 5.4 & 17.4 & 9.1 & .010 \\
\hline \multicolumn{6}{|l|}{ 入所予定者の薬剤而性菌スクリーニング g) } \\
\hline $\begin{array}{l}\text { 実施施設 } \\
\text { スクリーニング対象 h)（※複数回答） }\end{array}$ & 33.3 & 21.6 & 21.7 & 26.5 & .354 \\
\hline MRSA & 95.5 & 87.5 & 100.0 & 100.0 & .454 \\
\hline ESBL 産生菌 & 11.4 & 25.0 & 30.0 & 66.7 & .003 \\
\hline CRE & 6.8 & 12.5 & 10.0 & 44.4 & .030 \\
\hline MDRP & 13.6 & 25.0 & 20.0 & 88.9 & $<.001$ \\
\hline MDRA & 6.8 & 12.5 & 10.0 & 55.6 & .005 \\
\hline VRE & 6.8 & 12.5 & 10.0 & 66.7 & $<.001$ \\
\hline 対象菌がわからない & 6.8 & 0.0 & 0.0 & 0.0 & 1.000 \\
\hline \multicolumn{6}{|l|}{ 薬剂而性菌保菌者や感染者の受け入れ i）（※複数回答） } \\
\hline \multicolumn{6}{|l|}{ 入所に「検討が必要」または「不可」とされる保菌者や感染者 } \\
\hline MRSA 保菌者や感染者 & 51.2 & 27.7 & 15.9 & 15.7 & $<.001$ \\
\hline ESBL 産生菌保菌者や感染者 & 81.3 & 59.5 & 47.7 & 37.5 & $<.001$ \\
\hline CRE 保菌者や感染者 & 86.5 & 78.4 & 68.2 & 68.8 & .040 \\
\hline MDRP 保菌者や感染者 & 82.0 & 67.6 & 72.7 & 59.5 & .016 \\
\hline MDRA 保菌者や感染者 & 85.7 & 81.1 & 70.4 & 59.4 & .009 \\
\hline VRE 保菌者や感染者 & 83.5 & 75.7 & 63.6 & 62.5 & .019 \\
\hline
\end{tabular}

MRSA : Methicillin resistant Staphylococcus aureus, メチシリン耐性ブドウ球菌；ESBL：Extended spectrum $\beta$-lactamases, 基質特異性拡張型 $\beta$ ラクタマーゼ；CRE：Carbapenem resistant enterobacteriaceae, カルバペネム而性腸内細菌科細菌； MDRP : Multidrug resistant Pseudomonas aeruginosa, 多剂耐性緑膿菌; MDRA : Multidrug resistant Acinetobacter spp, 多 剂耐性アシネトバクター属菌；VRE Vancomycin resistant Enterococcus, バンコマイシン耐性腸球菌.

a）介護老人福祉施設；b）介護老人保健施設；c）介護療養型医療施設；d）Fisher の正確確率検定；e）薬剂而性菌種類, 薬 剂而性菌の抗菌薬感受性, 入院中の抗菌薬治療, 退院時の処方抗菌薬, 必要な感染対策, 本人・家族へ説明; f $)$ 無回答は有料 老人ホーム 7 件, 療養型 1 件；g）無回答は有料老人ホーム 5 件のみ；h） $\mathrm{n}$ は薬剂耐性菌スクリーニング実施施設のみ（有料 老人ホーム 44 件, 特養 8 件, 老健 10 件, 療養型 9 件）；i）無回答は有料老人ホーム 4 件, 老健 2 件, 療養型 2 件.

37.5 86.5\%の施設が $\mathrm{ESBL}$ 産生菌・CRE・MDRP・ MDRA・VRE 保菌者や感染者の入所を拒否 (入所に「検 討が必要」または「不可」)していた．理由は，MRSA と他の薬剤耐性菌では異なっていた。図3に, MRSA と ESBL 産生菌保菌者や感染者の入所拒否に関する理 由を示す. 入所拒否の主な理由は, MRSA では「細菌 検査ができない」「受け入れ経験がない」「マニュアルが ない」ことが, ESBL 産生菌では「受け入れ経験がない」 「マニュアルがない」「職員の知識不足」であった.

\section{8）AMR 対策上の課題}

AMR 対策上の課題は多い順に, 有料老人ホームでは 「職員の知識不足 $(65.0 \%) 」 「$ 職員の教育機会の不足 $(57.7 \%) 」$, 特養では「職員の知識不足 $(73.0 \%) 」 「 入$ 所 者の薬剂耐性菌保菌状態が不明 $(67.6 \%) 」$, 老健では, 「入 所者の薬剂耐性菌保菌状態が不明 (76.1\%)」「入所予定 者の薬剤耐性菌情報収集不足 $(58.7 \%) 」$, 療養型では「感

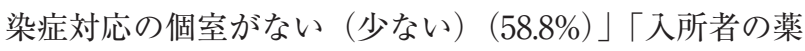

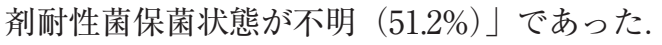

その他, 自由記載欄には「病院と老人ホームの背景の 


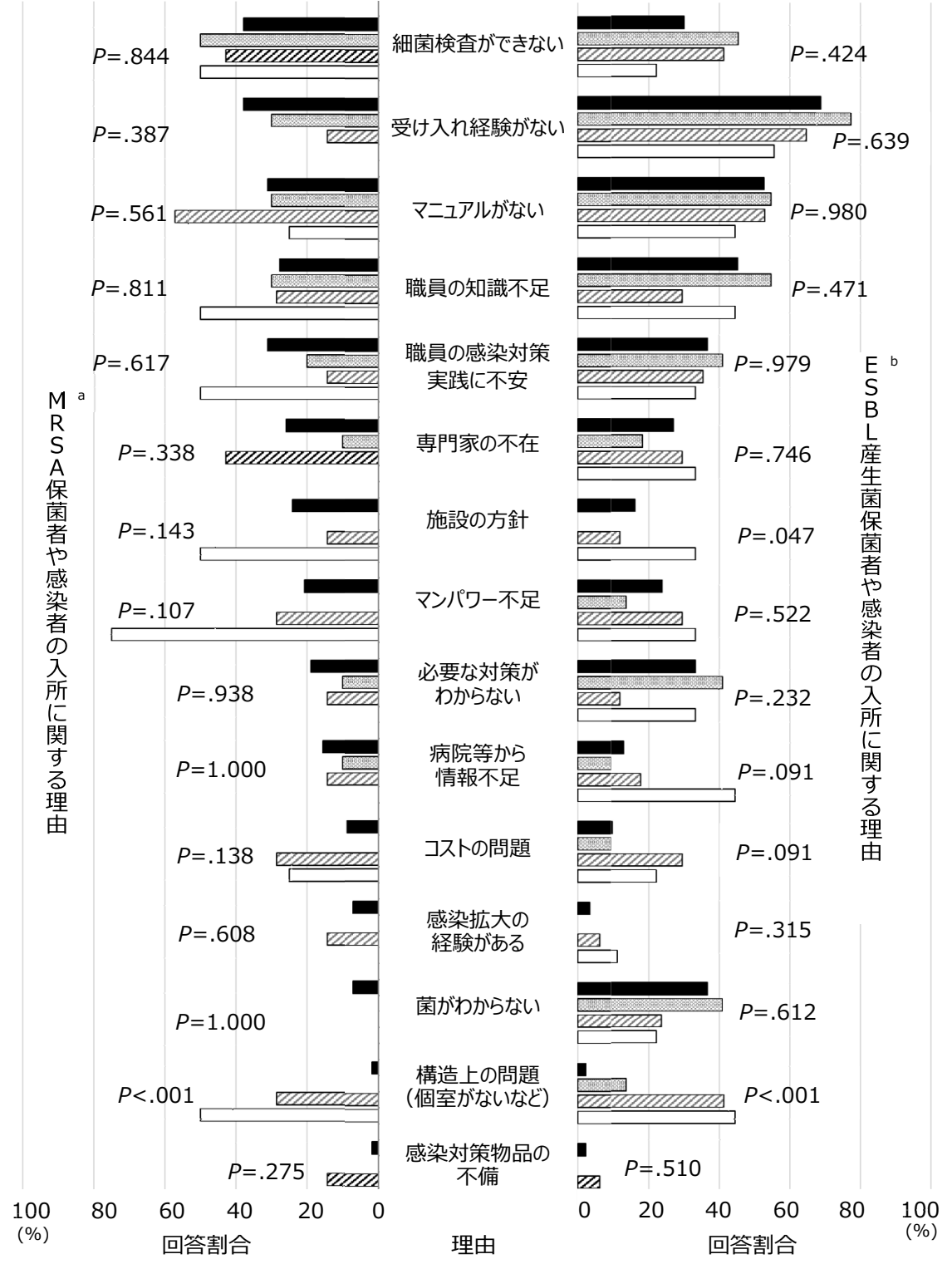

図 $3 \mathrm{MRSA} \cdot \mathrm{ESBL}$ 産生菌保菌者や感染者の入所に「検討が必要」または「不可」である理由 有料老人ホーム $\square$ 介護老人福祉施設（特養）

介介護老人保健施設（老健） $\square$ 介護療養型医療施設（療養型）

MRSA：Methicillin resistant Staphylococcus aureus メチシリン耐性ブドウ球菌；ESBL：Extended spectrum $\beta$-lactamase 基質特異性拡張型 $\beta$ - ラクタマーゼ.

a $\mathrm{n}$ は, MRSA 保菌者の入所に「検討が必要」または「不可」とする施設のみ回答 ; 有料老 人ホーム 68 件 (無回答 11 件), 特養 11 件 (無回答 1 件), 老健 7 件, 療養型 5 件（無回答 1 件).

$\mathrm{b} \mathrm{n}$ は, ESBL 産生菌保菌者の入所に「検討が必要」または「不可」とする施設のみ回答; 有 料老人ホーム 108 件 (無回答 11 件), 特養 22 件 (無回答 1 件), 老健 21 件, 療養型 12 件 (無回答 1 件).

違いを理解してもらいたい」「生活の場である」「AMR 対策の必要性があるのか疑問」「AMR 対策が必要な入 所者はいない」「今のままで満足」「医師が常駐しており 特に困っていない」との意見があった．他方，「施設で は薬剂耐性菌には意識が薄く対策もできていない」 $\lceil\mathrm{AMR}$ 対策のため (の) 病院との連携は無く意識も低
い」「(病院で) 新たな薬剤耐性菌が発生した場合に情報 がほしい」「病院からの情報が遅い」「入院して死亡され た入所者の（死因が）薬剤耐性菌感染など（であった場 合は, ) 十分注意し対応したい（と考えている）が，病 院からの情報がない」「施設は情報が少ないので病院や 保健所からの情報提供が欠かせない」「利用者の情報を 
（病院と）共有して相談診療できる医療連携が必要」「病 院の協力で施設の現状に合った AMR 対策のアドバイス とマニュアル作成に協力してもらいたい」「薬剤耐性菌 に対する適切な対応や認識に関して, 介護施設向けの情 報提供などがあるとよい」「病院での AMR 対策方法の 情報を得たい」「有効な AMR 対策を教えてもらいたい」 などの回答があった。

\section{9）施設類型別の実態}

(1) 有料老人ホーム

有料老人ホームは，医療職が少なかった（表 1).入 所定員は 30〜 60 人規模が多く，ほとんど個室であった. 入所者の在所日数は, 老健や療養型より長かった（ $p$ $<.001)$. 要介助 3 以上 $(p<.001)$, 認知症の日常生活 自立度ランク III 以上 $(p<.001)$, 麻痺 $(p<.001)$, 鱟 下障害がある入所者は $(p<.001), 3$ 種の介護保険施設 より少なかった，外部に AMR 対策を相談している施設 は6 割であった（表 2)。薬剤耐性菌を拡げやすいケア が必要な入所者も少ない傾向にあった（表 3-1，2）。3 種の介護保険施設よりも保菌者や感染者の受け入れを拒 否する傾向にあり, 受け入れ率はMRSA が 5 割未満, ESBL 産生菌, CRE, MDRP, MDRA, VREが 2 割未 満であった (表 4). 他方, 病院からの入所者比率は, 他 の施設類型と同様に高率であった. 薬剤耐性菌集団感染 も他の施設類型と同様に発生していた.

（2）特養

特養の入所定員は 50 95人規模が多く, 医療処置や ケアが必要な入所者比率が高いこと以外は, 有料老人 ホームに類似していた。医療職が少なく，個室が多く， 在所期間が長い傾向にあった．外部に AMR 対策を相談 している施設は 7 割であった。 保菌者や感染者の受け入 れ率は, MRSA が 7 割, ESBL 産生菌, CRE, MDRP, MDRA, VREが 2〜 4 割であった.

(3) 老健

老健の入所定員は $70 \sim 100$ 人規模が多く, 有料老人 ホームや特養より個室が少なかった $(p<.001)$. 老健で は, 療養型に比べ医療職は少なかったが, 併存疾患や医 療処置・ケアが必要な入所者比率はほぼ同等であった。 外部に AMR 対策を相談している施設は 7 割であった. 保菌者や感染者の受け入れ率は MRSA が約 8 割, ESBL 産生菌が約 5 割であったが, CRE, MDRP, MDRA, VRE では有料老人ホームや特養と同様に 3〜 4 割と低かった.

\section{（4）療養型}

療養型は, 医療処置やケアが必要な入所者比率は高 かったが, 他の 3 つの施設類型とは大きく異なっていた. 医療職が多かった。日常的に実施できる細菌検査も多く, 施設外の感染管理専門家への相談や感染対策地域ネット ワークへの参加も活発であった. 保菌者や感染者の受け 入れ率は, 他の 3 つの施設類型より高い傾向にあった。

\section{考察}

\section{1. 高齢者施設における AMR 対策の課題}

先行調查では, 高齢者施設に包括的な感染対策マニュ アルは配備されていることがわかっている ${ }^{17 \sim 199}$. 本調査 では AMR 対策マニュアルの配備率は 5 割程度であった が，ほとんどが MRSA 対策に限られていた。 AMR 対 策マニュアルが配備されていない理由は 2 点考えられる. 1 点目は, AMR 対策の必要性を職員が認識していなかっ たことである．本調査では「AMR 対策が必要な入所者 がほぼいない」「生活の場であるため AMR 対策の必要 性があるのか疑問」などの回答があった． 2 点目は，人 的リソースが少なかったことである. 感染管理担当者を 配置する高齢者施設は 4〜6 割であった。

高齢者施設では, MRSA 対策以外の研修が少なかっ た。研修は標準予防策実践を促進し ${ }^{25)}$, 手指衛生教育は 薬剤耐性菌保菌率を下げる ${ }^{26)}$. 本調査では，4～6 割の高 齢者施設が, 地域病院の専門家による研修会を希望して いた．高齢者施設で AMR 対策研修を推進するためには, 地域の病院からの支援が必要と考える. 既に, 感染症看 護専門看護師または感染管理認定看護師などの 4 割以上 は, 周辺地域の高齢者施設を支援し ${ }^{27)}$, 感染管理研修会 を行っている ${ }^{28,29)}$. しかし, 地域の高齢者施設をもれな くカバーし，地域のリソースを効率的に活用することは 困難であるため, 保健所が高齢者施設と中核病院を仲介 する役割を担うことが望ましいと考える。現在の感染防 止対策加算は, 中核病院が中小病院を支援することが要 件であるが，高齢者施設は支援対象ではない，そこで, 病院が地域の高齢者施設を支援すると診療報酬上の優遇 措置があったり，高齢者施設にも介護報酬上の優遇措置 （加算など）があったりするようなインセンティブも必 要と考える.

手指衛生については，マニュアルにケア手順に沿って タイミングを示していた施設は少なく, 職員全員に携帯 手指消毒剂を配布していた施設はわずか 5 ～17\% であっ た。個人防護具においても, マニュアルに着用タイミン グを示していた施設は少なく, 使用されない傾向にあっ た。高齢者施設では, 手指衛生や ${ }^{30)}$, 個人防護具の薬剤 耐性菌拡大防止効果は示されている ${ }^{31}$. したがって, 手 指衛生と個人防護具着用の夕イミングをケア手順に沿っ て示したマニュアルの整備が必要と考える.

2〜9 割の高齢者施設がおむつカートを使用しており, そのうち 6〜8 割では, カートに使用前後のおむつや裖 瘡処置の物品が混載されていた。 入所者が使用したおむ つは, $\mathrm{MRSA}^{32}$, ESBL 産生菌 ${ }^{33}$, カルバペネム耐性ア シネトバクターバウマニ に2 污染されている. 裷瘡には 薬剂耐性菌は定着しやすく ${ }^{6,7)}$, 裖瘡処置物品も污染され ている可能性がある。使用後のおむつや裖瘡物品を混載 しているおむつカートは薬剤耐性菌のリザーバーとなる。 
実際に，日本の高齢者施設では，ESBL 産生菌の拡大と おむつカートの使用の関連性が報告されている ${ }^{33}$. 薬剤 耐性菌のリザーバーとしてのおむつカートは廃止するべ きである，直ちに廃止できない場合には，清潔不潔物品 が混在しないよう清潔専用カートと不潔専用カートを配 備する必要がある。どちらのカートも居室内に持ち込ま ないようにし, 清潔物品が污染しないよう両カートは離 して置き使用ごとに清掃する必要がある.

裖瘡処置では，1～5 割の高齢者施設が軟膏類を複数 の入所者に使い回していた。裖瘡部には, 多剂耐性菌が 定着しやすい? ${ }^{734)}$. したがって, 軟膏類は使いまわさず 個人専用にする必要がある。

高齢者施設では，喀痰吸引や経管栄養に用いる単回使 用物品が再利用されていた. 再利用のために, 適切な消 毒工程を行っていない実態も明らかになった。内径が小 さいため洗いにくい喀痰吸引カテーテル, 経管栄養ライ ン，経鼻栄養チューブ，胃瘦・腸瘦専用接続チューブな どは, 洗えたとしても浸漬消毒時に薬液が内腔に満たさ れる必要があり, 効果的な洗浄・消毒は困難である. 特 に，高齢者施設における経管栄養は, MRSA ${ }^{5)}, \mathrm{ESBL}$ 産生菌 ${ }^{13)}, \mathrm{MDRP}^{10)}$, 薬剤耐性腸内細菌科細菌などの保 菌・感染リスクとなる ${ }^{9.11}$. 本調査では, 入居者の居室 やスタッフステーション, 食堂などの共用場所で経管栄 養物品の乾燥を行っていた。 高齢者施設のスタッフエリ アや入所者エリアの環境表面には薬剂耐性菌が定着して いる ${ }^{35)}$. 単回使用物品を洗浄してこれらの環境で乾燥さ せると薬剤耐性菌に污染される可能性がある。したがっ て, 喀痰吸引や経管栄養に用いる単回使用物品は, 再利 用しないことが重要と考える。再利用にかかる費用（洗 浄消毒費，人件費など）は単回使用費用を上回ることも 報告されている ${ }^{36,37)}$.

高齢者施設では, 入所予定者の薬剤耐性菌保菌状況に ついての情報を収集する施設は少なく, 日常的に細菌検 査が行える施設も 2 割以下であった。薬剤耐性菌スク リーニングや保菌状沉把握は, MRSA に限定される傾 向にあった，鼻腔スワブによる MRSA スクリーニング は 3〜 7 割の保菌者を見落す ${ }^{38,39)}$. 高歯者施設では, 見落 された保菌者や感染者には対策が行われないため, 薬剤 耐性菌を拡大するリスクが考えられる。また，スクリー ニング陽性者と陰性者を分けて行う対策は職員を混乱さ せる可能性もある。実際に，高齢者施設では，MRSA 以外の薬剂耐性菌 (ESBL 産生菌, CRE, MDRP, MDRA, VRE) による集団感染も発生しており, 特に ESBL 産 生菌による集団感染は MRSAによるものよりも多かっ た. 高歯者施設での現状の薬剤耐性菌スクリーニングで は，これらの保菌者や感染者を見落とす可能性が大きい. 本研究では, 多くの薬剂耐性菌保菌者や感染者が高齢 者施設に入所することができず，地域で行先を失ってい
る可能性が示唆された. 厚生労働省では「高齢者介護施 設における感染対策マニュアル改訂版」で，薬剤耐性菌 の保菌等を理由にサービス提供を拒否してはならないと している ${ }^{40)}$. しかし, 本研究結果では, 15.9 86.5\%の 高齢者施設が薬剤耐性菌保菌者や感染者を, 「細菌検査 ができない」「受け入れ経験がない」「マニュアルがな い」「職員の知識不足」などを理由に入所を拒否してい た。保菌や感染の情報は受け入れの可否を判定するため の資料となっていた可能性も考えられた。高齢者施設の 現状の AMR 対策には，これまで述べてきた課題の他に 次項で述べる施設類型別の課題もある。したがって，そ のような課題を解決できる AMR 対策に変更しなければ, 高齢者施設での保菌者や感染者の受け入れは困難である と考える. 地域包括ケアシステムの強化に伴い, 病院に は早期退院の圧力がかかっている。病院では, 高齢者施 設の受け入れ拒否を恐れて，保菌に関する情報を高齢者 施設に積極的に提供しないモラルハザードが起こってい る可能性も推測される.

\section{AMR 対策の施設類型別課題}

1) 有料老人ホーム

有料老人ホームを対象とした AMR 対策の実態に関す る調査は本研究が初めてであった。 有料老人ホームは, 薬剂耐性菌が拡がりにくい条件が揃っていたが，薬剤耐 性菌集団感染が介護保険施設と同様に発生していた。

高齢者施設では多床室が薬剤耐性菌保菌リスクである が7.41), 有料老人ホームは, ほとんどが個室であった。経 管栄養や ${ }^{10,11)}$ ，おむつケアは薬剤耐性菌保菌リスクであ るが ${ }^{12,13)}$ ，経管栄養やおむつケアが必要な入所者割合は 少なかった. 認知症, 嚥下障害, 麻痺の入所者割合も少 なかった．認知症入所者棟では，入所者や医療従事者の 高頻度接触面の細菌污染が他の入所者棟より高いことが わかっている ${ }^{42)}$. 認知症や ${ }^{31,43)}$, 舆下障害は薬剤耐性菌 保菌リスクであり ${ }^{44}$, 麻痺は感染リスクであることが指 摘されている9). したがって, 有料老人ホームは, 薬剤 耐性菌拡大リスクが他の施設類型よりも低いと考えられ た。しかし，薬剤耐性菌集団感染は介護保険施設と同様 に発生していた，有料老人ホームで薬剤耐性菌が拡がり やすい理由として 3 点が考えられる．1点目は病院から の入所者比率が介護保険施設と同様に高率であるからで ある．本調査の結果では， $75.9 \%$ であった，入院歴は薬 剂耐性菌保菌リスクである ${ }^{4,12}$. 2 点目は医療職が少ない からである. 看護師数の中央值は 4.3 人/施設であった. 看護師の配置不足は, MRSA 感染リスクである ${ }^{45)}$. 有料 老人ホームでは, 入所者のフィジカルアセスメントが夕 イムリーにできず，感染兆候の早期発見ができない可能 性が考えられる。介護職は感染症や感染予防策に対する 認識や実施状況が, 看護職より少ない傾向にあることが 報告されている ${ }^{25)}$. 3 点目は, マニュアルに接触予防策 
の記載が不十分であるからである. ケア前後の手指衛生 や個人防護具交換のタイミングの記載が少ない傾向に あった。

\section{2）介護保険施設（特養，老健，療養型）}

特養は, 老健や療養型に比べ医療職が少なく, 日常的 に細菌検査（外部委託を含む）を行う施設が少ない点に おいて有料老人ホームに類似していた。 入所者の在所日 数は, 老健や療養型より長かった。長期在所は, 薬剤耐 性菌保菌リスクである ${ }^{46)}$. 他方, 併存疾患がある入所者 比率や，医療処置やケアが必要な入所者比率が有料老人 ホームより高い傾向にあった。 したがって, 特養も薬剤 耐性菌拡大リスクが高いと考える.

老健は医療職が少なく, 個室が少なかった。医療処置 やケアが必要な入所者比率は療養型と同程度に高かった. したがって, 老健も薬剤耐性菌拡大リスクが高いと考え る.

療養型はこの 10 年で施設数が半減し ${ }^{47)}$, 介護医療院 へ転換中である。療養型は, 特養や老健よりも医療処置 やケアが必要な入所者比率が高い傾向にあり, 個室も少 なかった．しかし，他の 3 つの施設類型とは異なり医療 職が多く，ほぼすべての施設で日常的に細菌検査を行っ ていた，施設外の感染管理専門家への相談や感染対策地 域ネットワークへの参加も活発であり, 他の 3 つの施設 類型とは薬剤耐性菌拡大対策の状況が異なっていた.

\section{3. 高齢者施設における AMR 対策のあり方}

療養型は他の施設類型とは異なり, 病院に近い状況で あるため, 病院に準じた AMR 対策が良いと考える.

他方, 有料老人ホーム, 特養, 老健では保菌者や感染 者の把握は不十分であり, 潜在的な保菌者や感染者に防 止策が行われないことによる薬剤耐性菌拡大のリスクが 示唆された。本研究では, 4〜 19\%の高齢者施設が薬剤 耐性菌集団感染を把握していた。 しかし, 日常的に一般 細菌培養検査を実施していた施設は, 老健では $63 \%$ あっ たものの, 特養では $19 \%$, 有料老人ホームでは $14 \%$ の みであった。そのため, 高齢者施設が把握している集団 感染の現状は氷山の一角である可能性があり, 実際は もっと多いと考えられる.

これを改善するためには，二つの方法が考えられる。 一つ目は, 保菌者を洩れなく把握して接触予防策を実施 するために，全入所予定者にすべての薬剤耐性菌をスク リーニングすることである。 しかし，スクリーニングで はすべての保菌者を把握できないため偽㓌性保菌者に対 策をしないことによる感染拡大の危険性がある。また， スクリーニング結果が分かるまでのタイムラグによる対 策開始の遅れ, 保菌者と非保菌者に分けた対策による職 員の混乱, スクリーニングにかかる費用, 保菌者の入所 拒否に伴う人権侵害の懸念がある。もう一つの方法は, 入所時スクリーニングを中止し，すべての入所者に薬剤
耐性菌を拡げやすいケア時（尿道留置カテーテルの管理, おむつケア, 裖瘡処置, 喀痰吸引, 口腔ケア, 経管栄養) と薬剂耐性菌を拡げやすい感染症状（下痢, 呼吸器症状, 皮膚症状など）がある場合に標準予防策に加えて接触予 防策を実施することである。この方法の利点は，入所後 すぐに全員に同じ対策を行え，職員が混乱しにくく，ス クリーニング費用を削減でき, 保菌者の入所拒否が起こ りにくくなる可能性があることである， 欠点は，保菌し ていない入所者にも接触予防策を追加することによる手 袋やガウンなどの費用がかかることである．高齢者施設 における集団感染による費用損失は AMR 対策費用より 高額である ${ }^{48}$. AMR 対策（標準予防策および，すべて の入所者のおむつケアなどのハイリスクケア時に手袋と ガウンを使用）費用は, 1 人 1 カ月当たり約 23,000 円で ある ${ }^{49)}$. 他方, 高齢者施設における MRSA 集団感染に よる費用損失額（細菌検査, 抗菌療法, 個人防護具, 人 的・材料費用，環境清掃，特定部門の閉鎖などの費用） は 1 人 1 ケ月当たり約 300,000 円である ${ }^{48)}$. したがって, AMR 対策の費用対効果は良いと考える.

2019 年 7 月に公表された米国疾病予防管理センター Centers for Disease Control and Prevention (CDC) の 高齢者施設の薬剤耐性菌対策ガイドラインでは年，新た に強化バリア予防策（enhanced barrier precautions）が 提案された。背景には，これまでの標準予防策と接触予 防策だけでは，見落とされた保菌者からの薬剤耐性菌拡 大による深刻な問題がある。強化バリア予防策でも身体 接触が高いケア時の手袋とガウンの着用を锥奨している 著者が本研究で提案する方法との違いは，対象者である。 著者の提案ではすべての入所者を対象とするが, 強化バ リア予防策では感染者や保菌者, または創傷やデバイス がある入所者のみを対象とする。しかし，強化バリア予 防策では感染者や保菌者が把握できないことや, 保菌者 の予防策解除基準の問題などが解決されない. 入所者ご とに異なる対策を行うことは煩雑であり，対策が不十分 になる可能性がある。 また, 保菌者や感染者の入所拒否 にもつながりかねない.したがって, 高齢者施設の AMR 対策は，すべての入所者に薬剤耐性菌を拡げやすいケア 時と感染症状がある場合に標準予防策に加えて接触予防 策を実施する方法が必要と考える.

\section{4. 本研究の限界と課題}

本研究は回収率が低かった。二つの理由が考えられる。 一つ目は, 調査期間が 6 年ぶりの診療・介護報酬同時改 定，および「地域包括ケアシステム強化のための介護保 険法強化法」改正, 療養型の介護医療院転換と重なった ことである。:二つ目は, 施設長を介して対象者に調查票 を配布したことである. 全国の特養を対象とした感染対 策調査の施設長同意率は $6.7 \sim 7.1 \%$ と報告されてい $る^{51,52)}$ 。回収率の低さは, 高齢者施設の AMR 対策に関 
する認識の低さも推測される。したがって, 本調査の結 果は, 施設長が AMR 対策に一定の関心がある施設の実 態を反映していると考えられる. 本研究では, 調査回答 の催促や回答者への謝礼などの方法を検討する必要が あったと考える。今回, 回収率は低かったが, 入所定員, 個室割合, 職員数, 入所者の性別, 年齢, 平均在所日数, 要介護度, 認知症や併存疾患のある入所者比率, 医療処 置が必要な入所者比率の分布は，いずれの施設類型でも 先行調査の分布と類似していた ${ }^{33.54)}$. そのため, 本研究 で明らかにした高齢者施設の AMR 対策の実態は, 母集 団の実態とかけ離れてはいないのではないかと考える。

本研究では, 有料老人ホームと介護保険施設における AMR 対策の実態を明らかにした. しかし，高齢者施設 には，他に養護老人ホーム，軽費老人ホーム，サービス 付き高歯者向け住宅, 認知症高齢者グループホームなど がある、今後は，これらの施設における AMR 対策の実 態も明らかにする必要があると考える。

謝 辞：調查にご協力いただいた高齢者施設の管理者ならびに 感染管理担当者の皆様, 内容妥当性の検討, 予備調查にご協力い ただきました皆様に深く感謝申し上げます。本研究は, 著者吳禮 媛の国立研究開発法人国立国際医療研究センター国立看護大学校 特別研究論文 (修士学位論文) の一部です。また, 本研究成果の 一部は, 第 34 回日本環境感染学会総会・学術集会で発表しました. 本研究は JSPS 科研費 JP26293458, JP18H03079 の助成を受けた ものです.

利益相反自己申告：申告すべきものなし.

\section{文献}

1) Capitano B, Leshem OA, Nightingale $\mathrm{CH}$, Nicolau DP: Cost effect of managing methicillin-resistant Staphylococcus aureus in a long-term care facility. J Am Geriatr Soc 2003; 51(1): 10-6.

2) Richards C: Infections in residents of long-term care facilities: an agenda for research. Report of an expert panel. J Am Geriatr Soc 2002; 50(3): 570-6.

3) Venkatachalam I, Yang HL, Fisher D, Lye DC, Moi LL, Tambyah $\mathrm{P}$, et al:: Multidrug-resistant gram-negative bloodstream infections among residents of long-term care facilities. Infect Control Hosp Epidemiol 2014; 35(5): 519-26.

4) Flokas ME, Alevizakos M, Shehadeh F, Andreatos N, Mylonakis E: Extended-spectrum $\beta$-lactamase-producing Enterobacteriaceae colonisation in long-term care facilities: a systematic review and meta-analysis. Int $\mathrm{J}$ Antimicrob Agents 2017; 50(5): 649-56.

5) Mody L, Maheshwari S, Galecki A, Kauffman CA, Bradley SF: Indwelling device use and antibiotic resistance in nursing homes: identifying a high-risk group. J Am Geriatr Soc 2007; 55(12): 1921-6

6) Jans B, Schoevaerdts D, Huang TD, Berhin C, Latour K, Bogaerts $\mathrm{P}$, et al:: Epidemiology of multidrug-resistant microorganisms among nursing home residents in Belgium. PLoS One 2013; 8(5): e64908.
7) Suetens C, Niclaes L, Jans B, Verhaegen J, Schuermans A, Van EJ, et al: Determinants of methicillin-resistant Staphylococcus aureus carriage in nursing homes. Age Ageing 2007; 36: 327-30.

8) Chang CM, Lauderdale TL, Lee HC, Lee NY, Wu CJ, Chen PL, et al: Colonisation of fluoroquinolone-resistant Haemophilus influenzae among nursing home residents in southern Taiwan. J Hosp Infect 2010; 75(4): 304-8.

9) Rogers MA, Mody L, Chenoweth C, Kaufman SR, Saint S: Incidence of antibiotic-resistant infection in long-term residents of skilled nursing facilities. Am J Infect Control 2008; 36(7): 472-5.

10) Kanayama A, Kawahara R, Yamagishi T, Goto K, Kobaru $\mathrm{Y}$, Takano M, et al: Successful control of an outbreak of GES-5 extended-spectrum $\beta$-lactamase-producing Pseudomonas aeruginosa in a long-term care facility in Japan. J Hosp Infect 2016; 93(1): 35-41.

11) Sandoval C, Walter SD, McGeer A, Simor AE, Bradley SF, Moss LM, et al: Nursing home residents and Enterobacteriaceae resistant to third generation cephalosporins. Emerg Infect Dis 2004; 10(6): 1050-5.

12) Luvsansharav UO, Hirai I, Niki M, Nakata A, Yoshinaga A, Yamamoto A, et al: Fecal carriage of CTX-M $\beta$ lactamase-producing Enterobacteriaceae in nursing homes in the Kinki region of Japan. Infect Drug Resist 2013; 6: 67 70.

13）小野寺直人, 鈴木啓二朗, 高橋雅輝, 櫻井 滋, 諏訪部章 : 岩手県盛岡二次医療圈内の病院とその関連介護保険施設に 打ける基質特異性拡張型 $\beta$-ラクタマーゼ（ESBL）産生菌 の実態調查と要因分析. 感染症学雑誌 2016; 90(2): 105-12.

14）厚生労働省：平成 29 年介護サービス施設・事業所調査の概 況，図表データのダウンロード : https://www.mhlw.go.jp/ toukei/saikin/hw/kaigo/service17/index.html：2019 年 6 月 9 日現在.

15）厚生労働省：平成 29 年社会福祉施設等調查の概況, 図表 データのダウンロード : https://www.mhlw.go.jp/toukei/s aikin/hw/fukushi/17/index.html : 2019 年 6 月 9 日現在.

16）厚生労働省：第 100 回社会保障審議会介護給付費分科会資 料 4-2 施設・居住系サービスについて：https://www.mhl w.go.jp/file/05-Shingikai-12601000-Seisakutoukatsukan-Sanj ikanshitsu_Shakaihoshoutantou/0000044903.pdf : 2019 年 11 月 25 日現在

17）三菱総合研究所：平成 24 年度厚生労働省老人保健事業報告 書, 介護施設の重度化に対応したケアのあり方に関する調 查研究：https://www.mri.co.jp/project_related/hansen/up loadfiles/h24_05a.pdf : 2019 年 6 月 9 日現在.

18）村上啓雄：介護施設における薬剂耐性菌対策についての研 究「介護保険施設に扔ける薬剂耐性菌対策に関するアンケー 卜調查報告」: 平成 28 年度厚生労働科学研究費補助金分担 研究報告書, p. 29-44.

19）公益社団法人全国老人保健施設協会：介護施設に掞ける多 剂耐性菌を含む感染症への適切な対応のあり方に関する調 查研究事業報告書 : http://www.roken.or.jp/wp/wp-conten t/uploads/2012/07/H28_kansensyo_report.pdf：2019 年 11 月 25 日現在.

20）抗菌薬の適正使用に向けた 8 学会提言：抗菌薬適正使用支 援（Antimicrobial Stewardship：AS）プログラム推進のた めに: http://www.kankyokansen.org/modules/news/inde x.php?content_id $=161: 2019$ 年 11 月 25 日現在.

21）窪田志穂, 大城 聡, 森那美子, 網中眞由美, 秋山 徹, 切 替照雄, 他 : 多剂耐性菌アウトブレイク 1 施設で長期に渡 り流行した 2 凨以上耐性緑膿菌の伝播経路推定：日本環境 感染学会総会プログラム・抄録集 34 回 ; ワーク-7-3.

22）野村総合研究所：平成 28 年度老人保健事業推進費等補助金 高齢者向け住まいにおける認知症ケアや看取り, 医療ニー ズ等の重度化対応へのあり方に関する調查研究報告書 : htt 
ps://www.nri.com/ /media/PDF/jp/opinion/r_report/sya kaifukushi/20170410-4_report_1.pdf : 2019 年 11 月 25 日現 在.

23）総務省: 介護サービス施設・事業所調査/平成 28 年介護 サービス施設・事業所調查 詳細票編 介護保険施設 介護保 険施設の利用者：https://www.e-stat.go.jp/stat-search/file $\mathrm{s}$ ? page $=1 \&$ layout $=$ datalist $\&$ toukei $=00450042 \&$ tstat $=000001$ $029805 \&$ cycle $=7 \&$ tclass $1=000001106635 \&$ tclass $2=00000110$ $6640 \&$ tclass $3=000001106643 \&$ tclass $4=000001106676 \&$ stat_i $\mathrm{nfid}=000031627140: 2019$ 年 11 月 25 日現在.

24）脇坂 浩, 清水宣明：A 県の高齢者介護施設における感染 症対策のアンケート調査. 日本環境感染学会誌 2014; 29(5): 354-60.

25）小澤美紀, 矢代実希, 吉村恵美子：高齢者施設における職 員の感染予防策に関する認識と実施状況. 日本看護学会論 文集ヘルスプロモーション 2016; 46: 140-3.

26) Hocine MN, Temime L: Impact of hand hygiene on the infectious risk in nursing home residents: A systematic review. Am J Infect Control 2015; 43(9): e47-52.

27）一般社団法人日本感染管理ネットワーク：2017 年日本感染 管理ネットワーク会委員における感染管理活動調査 : htt p://www.asas.or.jp/icnj/pdf/chosa/2017doukou.pdf : 2019 年 6 月 9 日現在.

28）吹田夕起子, 福井幸子, 矢野久子, 前田ひとみ, 細川満子： 地域包括ケアを担う医療従事者を対象とした感染症対策研 修会の有効性と課題. 日赤秋田看大日赤秋田短大紀 2016; 21: $39-45$.

29）家入裕子：感染管理認定看護師と保健所を軸とした地域感 染対策ネットワークの構築. 山口県大学情報 2018; 11: 1-3.

30) Cheng V, Chen H, Wong SC, Chen J, Ng WC, So S, et al:: Role of Hand Hygiene Ambassador and Implementation of Directly Observed Hand Hygiene Among Residents in Residential Care Homes for the Elderly in Hong Kong. Infect Control Hosp Epidemiol 2018; 39(5): 571-7.

31) Blanco N, Pineles L, Lydecker AD, Johnson JK, Sorkin JD, Morgan DJ, et al:: Transmission of Resistant GramNegative Bacteria to Health Care Worker Gowns and Gloves during Care of Nursing Home Residents in Veterans Affairs Community Living Centers. Antimicrob Agents Chemother 2017; 61(10): e00790-17.

32) Cheng V, Chen H, Ng WC, Wong JY, Chow DM, Law TC, et al: Emergence of Carbapenem-Resistant Acinetobacter baumannii in Nursing Homes With High Background Rates of MRSA Colonization. Infect Control Hosp Epidemiol 2016; 37(8): 983-6.

33) Yokoyama K, Uehara Y, Sasaki T, Hiramatsu K: Risk factors of fecal colonization with extended-spectrum $\beta$ lactamase-producing Enterobacteriaceae in special nursing homes in Japan. J Gen Fam Med 2018; 19(3): 90-6.

34) Lim CJ, Cheng AC, Kennon J, Spelman D, Hale D, Melican G, et al: Prevalence of multidrug-resistant organisms and risk factors for carriage in long-term care facilities: a nested case-control study. J Antimicrob Chemother 2014; 69(7): 1972-80.

35) Cassone M, Mantey J, Perri MB, Gibson K, Lansing B, McNamara S, et al: Environmental Panels as a Proxy for Nursing Facility Patients With Methicillin-Resistant Staphylococcus aureus and Vancomycin-Resistant Enterococcus Colonization. Clin Infect Dis 2018; 67(6): 861-8.

36）伊藤真也, 鈴木俊敬, 浅井和浩, 鈴木美佐子, 山田卓也 : イルリガードルの洗浄による再使用は単回使用と比較し医 療費の削減に繋がるのか. 日静脈経腸栄会誌 2018; 33 Suppl: 295.

37）土田敏恵, 岩根敬子, 大西良子: 経腸栄養用コンテナの細 菌污染と経済性の評価。感染防止 1997; 7(5): 40-6.

38) Gibson KE, McNamara SE, Cassone M, Perri MB, Zervos
M, Mody L, et al:: Methicillin-resistant Staphylococcus aureus: site of acquisition and strain variation in high-risk nursing home residents with indwelling devices. Infect Control Hosp Epidemiol 2014; 35(12): 1458-65.

39) Mody L, Kauffman CA, Donabedian S, Zervos M, Bradley SF: Epidemiology of Staphylococcus aureus colonization in nursing home residents. Clin Infect Dis 2008; 46(9): 1368-73.

40）厚生労働省：高齢者介護施設における感染対策マニュアル 改訂版 (2019 年 3 月 : https://www.mhlw.go.jp/content/0 00500646.pdf : 2019 年 11 月 25 日現在.

41) Chen H, Au KM, Hsu KE, Lai CK, Myint J, Mak YF, et al: Multidrug-resistant organism carriage among residents from residential care homes for the elderly in Hong Kong: a prevalence survey with stratified cluster sampling. Hong Kong Med J 2018; 24(4): 350-60.

42）水谷伸也, 脇坂 浩：介護老人保健施設に打ける高頻度接 触表面の特定および環境表面の污染度調査. 感染管理看護 研究会誌 2017; 6(1): 1-5.

43) Mody L, Gibson KE, Horcher A, Prenovost K, McNamara SE, Foxman B, et al: Prevalence of and risk factors for multidrug-resistant Acinetobacter baumannii colonization among high-risk nursing home residents. Infect Control Hosp Epidemiol 2015; 36(10): 1155-62.

44) Pobiega M, Wojkowska-Mach J, Chmielarczyk A, Romaniszyn D, Adamski P, Heczko PB, et al: Molecular characterization and drug resistance of Escherichia coli strains isolated from urine from long-term care facility residents in Cracow, Poland. Med Sci Monit 2013; 19: 317-26.

45) Loeb MB, Craven S, McGeer AJ, Simor AE, Bradley SF, Low DE, et al: Risk factors for resistance to antimicrobial agents among nursing home residents. Am J Epidemiol 2003; 157(1): 40-7.

46) O'Fallon E, Schreiber R, Kandel R, D'Agata EM: Multidrug-resistant gram-negative bacteria at a long-term care facility: assessment of residents, healthcare workers, and inanimate surfaces. Infect Control Hosp Epidemiol 2009; 30(12): 1172-9.

47）厚生労働省：第 144 回社会保障審議会介護給付費分科会資 料, 参考資料 3 介護療養型医療施設及び介護医療院：http:// www.mhlw.go.jp/toukei/saikin/hw/kaigo/kyufu/16/index. $\mathrm{html}: 2019$ 年 6 月 9 日現在.

48) van Rijt AM, Dik JH, Lokate M, Postma MJ, Friedrich AW: Cost analysis of outbreaks with Methicillin-resistant Staphylococcus aureus (MRSA) in Dutch long-term care facilities (LTCF). PLoS One 2018; 13(11): e0208092.

49) Roghmann MC, Lydecker A, Mody L, Mullins CD, Onukwugha E: Strategies to Prevent MRSA Transmission in Community-Based Nursing Homes: A Cost Analysis. Infect Control Hosp Epidemiol 2016; 37(8): 962-6.

50) CDC: Implementation of Personal Protective Equipment (PPE) in Nursing Homes to Prevent Spread of Novel or Targeted Multidrug-resistant Organisms (MDROs): http s://www.cdc.gov/hai/containment/PPE-Nursing-Homes.ht ml?deliveryName=USCDC_425-DHQP-DM11348. accessed November 25, 2019.

51）大浦絢子, 松下幸平, 青地鸟，岸本 剛，斎藤章暢，石 田篤史, 他 : 全国特別養護老人ホームにおける感染管理に 関する調査報告. 体力・栄・免疫誌 2014; 24(3): 213-5.

52）大浦絢子, 加藤裕子：高齢者介護施設における感染症発生 と予防・対応策との関連. 早稲田大学審査学位論文 : http s://waseda.repo.nii.ac.jp/?action=pages_view_main\&active _action=repository_view_main_item_detail\&item_id $=4123$ $5 \&$ item_no $=1 \&$ page_id $=13 \& b l o c k \_i d=21: 2019$ 年 6 月 9 日 現在.

53）総務省: 平成 28 年介護サービス施設・事業所調査 詳細票 編. 政府統計の空口 e-Stat：http://www.e-stat.go.jp/SG1/e 
stat/GL08020101.do?_toGL08020101_\&tstatCode $=00000102$ $9805 \&$ requestSender $=\mathrm{dsearch}: 2019$ 年 6 月 9 日現在.

54）野村総合研究所：平成 28 年度老人保健事業報告書, 高齢者 向け住まいおよび住まい事業者の運営実態に関する調査研 究 : https://www.mhlw.go.jp/file/06-Seisakujouhou-123000 00-Roukenkyoku/71_nomura.pdf：2019 年 6 月 9 日現在.
〔連絡先：〕204-8575 東京都清瀬市梅園 1-2-1

国立看護大学校 呉 禮媛/西岡みどり

E-mail: ohyeiwon@d19.ncn.ac.jp / nishiokam@adm.ncn. ac.jp]

\title{
Antimicrobial Resistance Measures at Facilities for the Elderly: A Fact-finding Survey on Infection Control Measures at Private Nursing Homes and Long-term Care Insurance Facilities
}

\author{
Yeiwon $\mathrm{OH}^{1,2)}$, Mayumi AmINAKA ${ }^{1)}$, Namiko MORI ${ }^{1)}$ and Midori NishiOKA ${ }^{1)}$ \\ ${ }^{1)}$ National College of Nursing, ${ }^{2)}$ Akiru Municipal Medical Center
}

\section{Abstract}

The objective of this study was to examine the nature of antimicrobial resistance (AMR) measures by clarifying the actual state of such measures at private nursing homes and long-term care insurance facilities. Infection control staff at a total of 2,800 randomly sampled facilities for the elderly (private nursing homes, designated facilities covered by public aid providing long-term care to the elderly, long-term care health facilities, and medical long-term care sanatoriums) were surveyed using a self-administered questionnaire.

The responses of 254 (9.1\%) facilities were tabulated. The conditions for hindering the spread of antimicrobial-resistant bacteria were being met at private nursing homes, but outbreaks of methicillin-resistant Staphylococcus aureus (MRSA), extended spectrum beta-Lactamaseproducing bacteria, carbapenem-resistant Enterobacteriaceae, multidrug-resistant Pseudomonas aeruginosa, multidrug-resistant Acinetobacter, and vancomycin-resistant enterococci infections had occurred like at other types of facilities. AMR measures at facilities for the elderly, such as availability of manuals, training, and measures upon admission, were insufficient. Screening upon admission was only implemented at $22 \%-33 \%$ of the facilities, and the target bacterium in screening was almost always limited to MRSA. There were also issues with care that facilitates the spread of antimicrobial-resistant bacteria (such as urethral indwelling catheter management and diaper care). Accordingly, this demonstrated the risk of the spread of antimicrobial-resistant bacteria from overlooked carriers.

These findings suggest that because AMR measures at facilities for the elderly do not require screening upon admission, it may be effective to strengthen contact precautions in addition to standard precautions during provision of care that facilitates the spread of antimicrobial-resistant bacteria to all residents. Medical care and long-term care fee incentives are also needed to promote support from public health centers and regional core hospitals.

Key words: nursing home, long-term care facility, antimicrobial resistance, healthcare-associated infection, infection control 